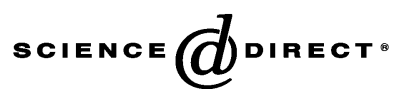

Earth-Science Reviews 68 (2005) 173-196

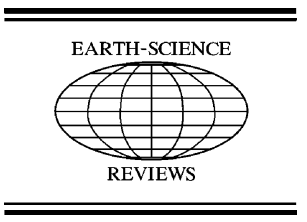

www.elsevier.com/locate/earscirev

\title{
Tibetan tectonic evolution inferred from spatial and temporal variations in post-collisional magmatism
}

\author{
Sun-Lin Chung ${ }^{\mathrm{a}, *}$, Mei-Fei Chu ${ }^{\mathrm{a}}$, Yuquan Zhang ${ }^{\mathrm{b}}$, Yingwen Xie ${ }^{\mathrm{b}}$, Ching-Hua Lo ${ }^{\mathrm{a}}$, \\ Tung-Yi Lee ${ }^{\mathrm{c}}$, Ching-Ying Lan ${ }^{\mathrm{d}}$, Xianhua Li ${ }^{\mathrm{b}}$, Qi Zhang ${ }^{\mathrm{e}}$, Yizhao Wang ${ }^{\mathrm{f}}$ \\ ${ }^{a}$ Department of Geosciences, National Taiwan University, Taipei P.O. Box 13-318, Taipei 10699, Taiwan \\ ${ }^{\mathrm{b}}$ Guangzhou Institute of Geochemistry, Chinese Academy of Sciences, Guangzhou, China \\ ${ }^{\mathrm{c}}$ Department of Earth Sciences, National Taiwan Normal University, Taipei, Taiwan \\ ${ }^{\mathrm{d}}$ Institute of Earth Sciences, Academia Sinica, Taipei, Taiwan \\ ${ }^{\mathrm{e}}$ Institute of Geology and Geophysics, Chinese Academy of Sciences, Beijing, China \\ ${ }^{\mathrm{f}}$ Regional Geological Survey, Yuxi, Yunnan, China
}

Received 24 June 2003; accepted 5 May 2004

\begin{abstract}
Cenozoic magmatism on the Tibetan plateau shows systematic variations in space and time that must be considered in models concerning Tibetan tectonic evolution. After the India-Asia collision, which started in the early Tertiary and terminated the Gangdese arc magmatism in the Lhasa terrane made of the southern Tibetan plateau, widespread potassium-rich lavas and subordinate sodium-rich basalts were generated from $\sim 50$ to $30 \mathrm{Ma}$ in the Qiangtang terrane of northern Tibet. Subsequent post-collisional magmatism migrated southwards, producing ultrapotassic and adakitic lavas coevally between $\sim 26$ and $10 \mathrm{Ma}$ in the Lhasa terrane. Then potassic volcanism was renewed to the north and has become extensive and semicontinuous since $\sim 13 \mathrm{Ma}$ in the western Qiangtang and Songpan-Ganze terranes. Such spatial-temporal variations enable us to elaborate a geodynamic evolution model which depicts when and how the Indian continental lithospheric mantle started thrusting under Asia by involving rollback and breakoff of the subducted Neo-Tethyan slab followed by removal of the thickened Lhasa lithospheric root. We propose that only after the lithospheric removal, which occurred at $\sim 26 \mathrm{Ma}$, could the Indian mantle lithosphere have commenced its northward underthrusting and henceforth served as a pivotal control to the Himalayan-Tibetan orogenesis. Consequently, the Tibetan plateau is suggested to have risen diachronously from south to north. Whereas the southern part of the plateau may have been created and maintained since the late Oligocene, the northern plateau would have not attained its present-day elevation and size until the mid-Miocene when the lower part of the western Qiangtang and SongpanGanze lithospheres began to founder owing to the push of the underthrust Indian mantle lithosphere.
\end{abstract}

(C) 2004 Elsevier B.V. All rights reserved.

Keywords: Tibetan plateau; Continental tectonics; Post-collisional magmatism; Geochemistry; India-Asia collision

\section{Introduction}

* Corresponding author. Tel.: +886-2-8369-1242; fax: +886-22363-6095.

E-mail address: sunlin@ntu.edu.tw (S.-L. Chung).
It is widely accepted that the immense Tibetan plateau and surrounding mountain ranges form as a direct consequence of the collision of India with Asia 
starting in the early Cenozoic. The plateau, which represents the most outstanding natural laboratory on the Earth for studying continental collision orogenesis (cf. Allegrè et al., 1984; Molnar et al., 1993) and its influence on global ocean and climatic change (Molnar et al., 1993; Zhang et al., 2001; and references therein), has been the subject of numerous investigations. There have been a wide variety of hypotheses proposed for Tibetan tectonic evolution, such as distributed crustal shortening and thickening (England and Houseman, 1986), convective removal of tectonically thickened Asian lithospheric mantle (Houseman et al., 1981; Platt and England, 1994), block extrusions along principal strike-slip faults (Tapponnier et al., 1982, 2001), northward injection of the Indian crust (Zhao and Morgan, 1985), thrusting of the Indian mantle lithosphere under Asia (Klootwijk et al., 1985; Powell, 1986; Owens and Zandt, 1997; Chemenda et al., 2000), and southward "subduction" of the Asian continental lithosphere under Tibet (Willett and Beaumont, 1994; Roger et al., 2000). Debates essentially concern two fundamental questions: (1) when did the plateau start to rise (Harrison et al., 1992; Molnar et al., 1993; Turner et al., 1993; Coleman and Hodges, 1995; Chung et al., 1998; Blisniuk et al., 2001; Williams et al., 2001) and (2) how was its remarkably uniform elevation $(\sim 5 \mathrm{~km}$ above sea level) attained and sustained (Bird, 1991; Beghoul et al., 1993; Fielding et al., 1994; Fielding, 1996; Hodges, 2000; Spicer et al., 2003). Recent geophysical and geological studies indicate that the Tibetan plateau has a heterogeneous structure in the crust and lithospheric mantle (Nelson et al., 1996; Owens and Zandt, 1997; Yuan et al., 1997; Hacker et al., 2000; Huang et al., 2000; Wei et al., 2001; Zhao et al., 2001a) and widespread post-collisional magmatism (Turner et al., 1993, 1996; Chung et al., 1998; Deng, 1998; Miller et al., 1999; Li et al., 2002; Chung et al., 2003; Ding et al., 2003). These features make it unlikely that the entire plateau was caused by any single event and point to a new challenge of exploring how heterogeneous features in the Tibetan lithosphere are linked with various geodynamic processes that evolved at depth to achieve the uniform surface appearance.

In this paper, instead of reviewing numerous works in the literature, we synthesize the distribution, age, and geochemical data of the post-collisional igneous rocks from the Tibetan plateau. This synthesis leads us to identify four principal magma suites with regard to space and time. The spatial and temporal variations observed in these magmas, which comprise a dominant group of potassic lavas derived from the enriched lithospheric mantle and collision-type adakites produced by partial melting of thickened mafic lower crust in the Lhasa terrane, imply the thermal structure of Tibetan deep lithosphere to have also evolved. We therefore argue that our synthesis puts new and presumably straightforward constraints on studies of how the spatially and temporally heterogeneous geodynamic processes were involved in the formation of the plateau. These synthesized data were then used, together with geological and geophysical information, to propose a new model for Tibetan tectonomagmatic evolution. We propose that starting from the south with a narrow mountain range along the Gangdese arc, this part of the Tibetan plateau underwent two major stages of uplift in the Eocene and late Oligocene, owing to detachment of the Neo-Tethyan slab at $\sim 45 \mathrm{Ma}$ and loss of thickened Lhasa lithospheric mantle root at $\sim 26 \mathrm{Ma}$. The entire plateau, however, did not attain its present elevation and size until $\sim 13$ Ma when the lower portion of thickened lithospheric mantle of the western Qiangtang and Songpan-Ganze terranes in northern Tibet began to be destroyed by underthrusting of the Indian mantle lithosphere.

\section{Geological and geophysical background}

Asia is a collage of continental fragments assembled mainly in the Paleozoic and Mesozoic, with the latest amalgamation occurring when India began colliding with it in early Cenozoic time (Lee and Lawver, 1995; Rowley, 1998; Hodges, 2000; and references therein). A direct consequence of this collision is the birth of the Himalayas and Tibetan plateau, which are separated from each other by the Indus-Tsangpo suture (Fig. 1). This suture delineates the juxtaposition of Indian continental shelf sediments against Asian rocks after the closure of Neo-Tethys ocean. Before the collision, the surface area of the Indian block was much larger and this "Greater India" extended $>1000$ $\mathrm{km}$ farther north beyond the modern Himalayan mountain front (cf. DeCelles et al., 2002). Thus, a main part of the missing crust of Greater India is 


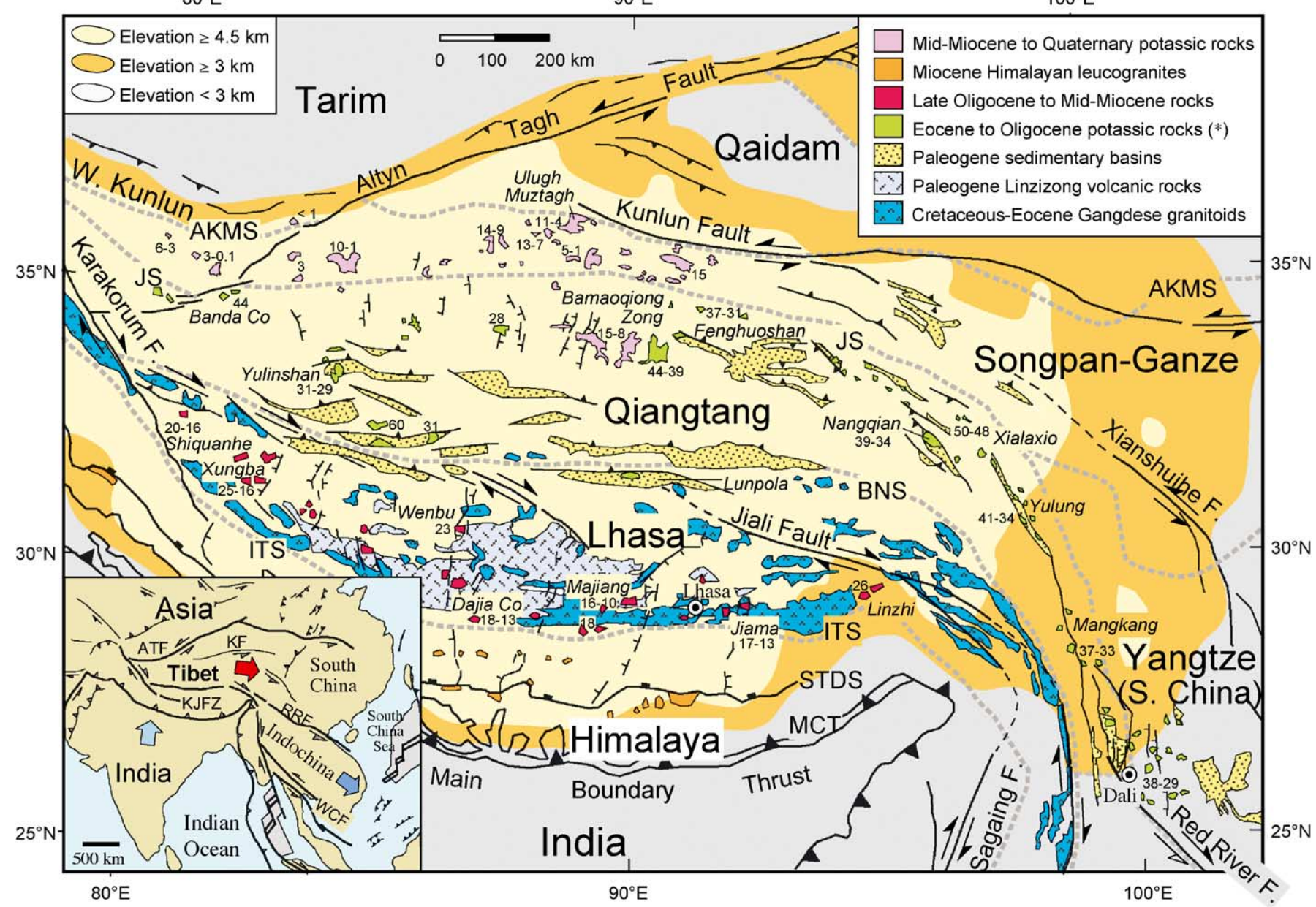

Fig. 1. Simplified geological map of the Tibetan plateau and surrounding areas (modified from Chung et al., 1998, 2003; Yin and Harrison, 2000; Tapponnier et al., 2001). Ages of post-collisional potassic magmas are shown in numerals, data sources are given in Fig. 2. An asterisk in the legend for magmatic rocks remarks that Paleocene (60 Ma) sodium-rich basalts emplaced in the western Qiangtang are included. Elevations of the plateau are after Fielding et al. (1994). Inset shows the Cenozoic tectonic extrusion in East Asia related to the India-Asia collision (after Tapponnier et al., 1982). MBT = Main Boundary Thrust; MCT = Main Central Thrust; STDS = South Tibet Detachment System; ITS = Indus - Tsangpo Suture; BNS = Bangong - Nujiang Suture; JS $=$ Jinsha Suture; AKMS $=$ Ayimaqin - Kunlun - Muztagh Suture; ATF $=$ Tltyn Tagh Fault; KF $=$ Kunlun Fault; KJFZ = Karakorum - Jiali Fault Zone; RRF = Red River Fault; WCF = Wang Chao Fault. 
deformed and buried underneath the Himalayas and southern Tibet along one of the north-dipping décollements, such as the Main Central Thrust (Fig. 1) that represents the most dominant crustal-scale structure in the region and recorded the Neohimalayan metamorphic history between $\sim 23$ and $18 \mathrm{Ma}$ (Hodges, 2000; Guillot and Allemand, 2002). Meanwhile, east-west-striking normal faulting took place along the South Tibetan Detachment System that played a key role in exposing the High Himalayan metamorphic core complex (Burchfiel et al., 1992). Therefore, the Miocene evolution of the Himalayan orogen is characterized by synchronous crustal shortening at deep structural levels along the thrust system but extension at shallow levels along the detachment system (Hodges et al., 1992). These tectonic activities may have served as an efficient mechanism (Hodges et al., 2001) that led to southward extrusion of the Tibetan crust, in a quasi-continuous (Hodges, 2000) or episodic (Searle, 1999) fashion, associated with the emplacement of crustally derived leucogranites (Le Fort et al., 1987; Harrison et al., 1997) along much of the Himalayas (Fig. 1).

The Tibetan plateau consists primarily of three terranes that are, from south to north, the Lhasa, Qiangtang, and Songpan-Ganze terranes, separated from each other by the Bangong-Nujiang and Jinsha sutures (Fig. 1), representative of the Meso- and Paleo-Tethyan relicts, respectively. Along with its uniform and high elevations, the plateau has a remarkable crustal thickness that is twice that of normal continental crust (Molnar et al., 1993). Recent studies indicate that the Tibetan crust is thickest $(\sim 70-80$ $\mathrm{km}$ ) under the Lhasa terrane and becomes $\sim 10-20$ $\mathrm{km}$ thinner in the Qiangtang and Songpan-Ganze terranes (Yuan et al., 1997; Zhao et al., 2001a). In addition to the prevailing strike-slip shears that developed essentially around the plateau (cf. Tapponnier et al., 2001), the presence of widespread northstriking normal faults in Tibet (Armijo et al., 1986; Molnar et al., 1993) reflects active east-west extension, although India is still moving northward at a rather uniform convergence rate of $\sim 5 \mathrm{~cm} /$ year relative to stable Eurasia (Paul et al., 2001; Wang et al., 2001b). Radiometric age data led to a general notion that Tibetan east-west extension began diachronously, with the north-striking normal faulting having been initiated at $\sim 18-14 \mathrm{Ma}$ in the southern plateau (Coleman and Hodges, 1995; Williams et al., 2001 ) and at $\sim 4 \mathrm{Ma}$ in the north (cf. Yin and Harrison, 2000). Nevertheless, Blisniuk et al. (2001) reported that in the central Qiangtang of northern Tibet the normal faulting also started in mid-Miocene time $(\sim 13.5 \mathrm{Ma})$. There are widespread Paleogene sedimentary basins developed in northern Tibet (Fig. 1), to which little attention had been paid until recent investigations of the Fenghuoshan (Hoh Xil) and Nangqian basins (Liu and Wang, 2001; Horton et al., 2002). These basins, occurring throughout the Qiangtang terrane and often associated with magmatism (see below), can be correlated southeastward with contemporaneous sedimentary basins that formed around the Red River fault zone in the westernmost part of the Yangtze craton or South China block (Fig. 1).

A large amount of geophysical information obtained by international collaborations has greatly advanced our understanding of the present-day lithospheric structure of the Tibetan plateau. The INDEPTH project (Nelson et al., 1996), for instance, suggests a partially molten zone in the middle crust of southern Tibet. Subsequent workers (e.g., Owens and Zandt, 1997; Yuan et al., 1997; Zhao et al., 2001a; Wei et al., 2001) repeatedly showed partial melts or aqueous fluids to be widespread in the Tibetan crust, despite the fact that volcanism is now active only in the northern plateau and crustal xenolith data from central Qiangtang (Hacker et al., 2000) do not support the presence of voluminous melts or fluids. Most recently, Galvé et al. (2002) and the INDEPTH III results (Haines et al., 2003) indicated that underneath the Qiangtang terrane there is no widespread partial melting feature in the deep crust. Based on teleseismic wave experiments over the Tibetan plateau, Owens and Zandt (1997) argued that there are systematic variations in crustal properties and correlations exist between the average crustal thickness and seismic Poisson's ratio. The correlations likewise appear to be coupled with changes in the upper mantle properties because the Tibetan crust and lithospheric mantle are under similar strain fields dominated by a left-lateral shear component (Holt, 2000). In the southern plateau, it is generally believed that the Indian mantle lithosphere has underthrust Asia to as north as the Bangong-Nujiang suture and the Lhasa lithospheric mantle keel seems to be mostly absent (Bird, 1991; 
Owens and Zandt, 1997; Kosarev et al., 1999; Zhao et al., 2001a). In the north, where there is a thin but complex lithospheric lid beneath the Qiangtang and Songpan-Ganze terranes (Kosarev et al., 1999; Kind et al., 2002), the upper mantle is anomalous in several seismic parameters, all of which indicate unusually high temperatures (McNamara et al., 1995; Huang et al., 2000). A sharp Moho offset has been observed along the northern margin of the plateau, interpreted as implying a weak Tibetan crust that thickens vertically in response to the Indian penetration from the south coupled with resistance from a more rigid crust in the Qaidam terrane from the north (Zhu and Helmberger, 1998).

\section{Post-collisional magmatism on Tibet}

The consensus on the initiation age of the IndiaAsia collision is on a small scale; estimates vary from as early as the Late Cretaceous (Yin and Harrison, 2000) to the latest Eocene (Rowley, 1998) or even later (Aitchison et al., 2002). Regardless of this controversy and additional complexities such as the diachronous onset of the collision (cf. Rowley, 1998), we adopt the plate motion reconstruction of Lee and Lawver (1995) which advocates a "soft collision" caused by contact of the margin of Greater India with Asia at $~ 60$ Ma followed by a "hard collision" since $\sim 45 \mathrm{Ma}$ (Fig. 2). We hence regard the collision

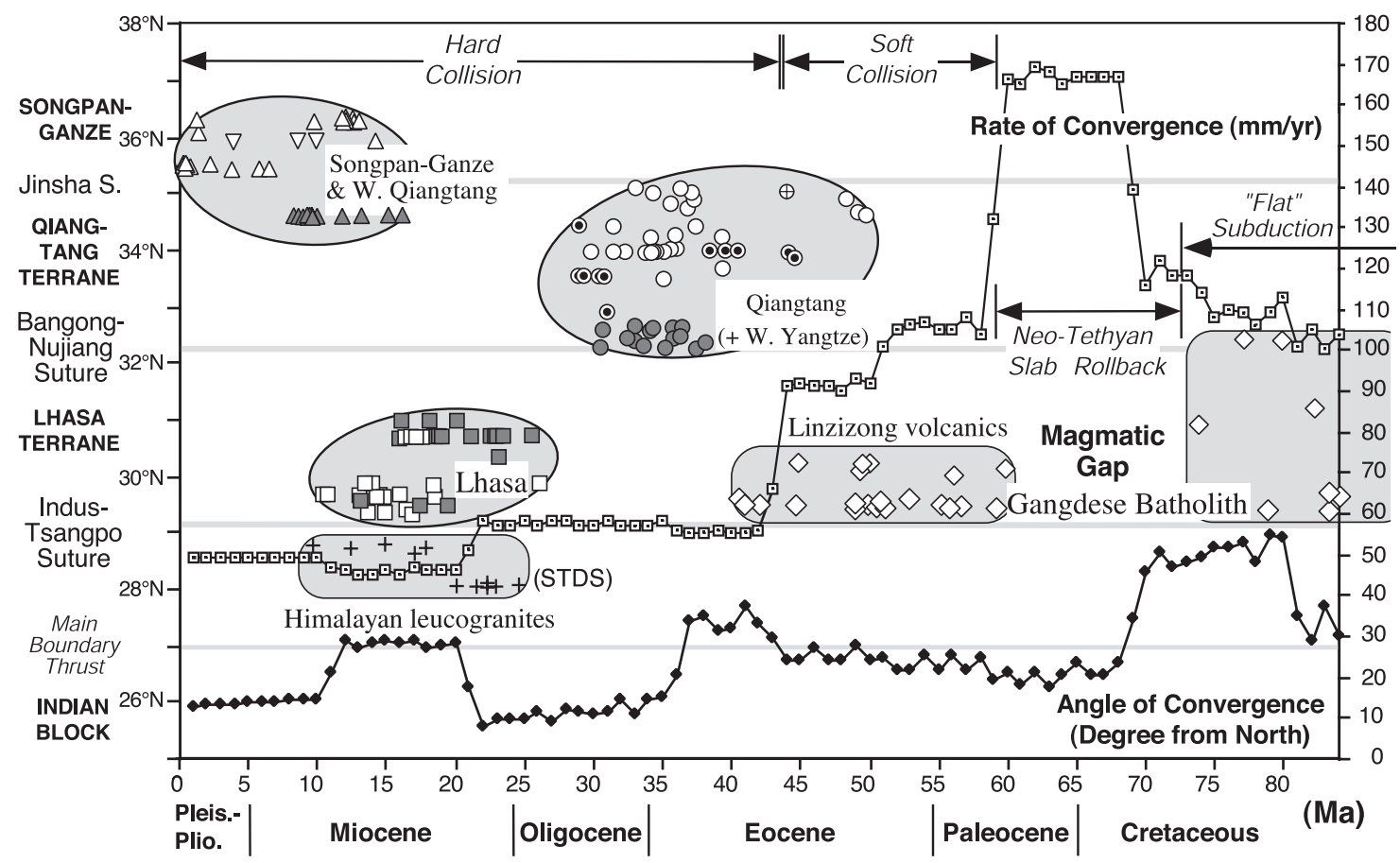

Fig. 2. Spatial variation in Tibetan magmatism (left-hand ordinate) and rate and angle of convergence between India and Asia (right-hand ordinate) through the Late Cretaceous to Quaternary time periods (abscissa). Note that in each terrane, the sample's latitudes were normalized to the $90^{\circ} \mathrm{E}$ north - south section and that the age data of samples from the southeastern Qiangtang and western Yangtze terranes (see Fig. 1) can thus be plotted in the locations. Data sources include: (1) Gangdese and Linzizong arc magmas (Schärer and Allègre, 1984; Xu et al., 1985; Coulon et al., 1986; Debon et al., 1986; Copeland et al., 1995; Lee et al., 2003b); (2) Himalayan leucogranites (Harrison et al., 1997; Searle, 1999); (3) Paleogene magmas from the Qiangtang and western Yangtze terranes (Chung et al., 1998; Deng, 1998; Ding et al., 1999, 2003; Hacker et al., 2000; Roger et al., 2000; Deng et al., 2001; Wang et al., 2001a; Chu et al., 2004); (4) late Oligocene-Miocene magmas from the Lhasa terrane (Coulon et al., 1986; Arnaud et al., 1992; Turner et al., 1996; Miller et al., 1999; Yin and Harrison, 2000; Williams et al., 2001; Chung et al., 2003; Ding et al., 2003; Spicer et al., 2003); (5) mid-Miocene to Quaternary magmas from the western Qiangtang and SongpanGanze terranes (Burchfiel et al., 1989; Arnaud et al., 1992; Turner et al., 1993, 1996; Deng, 1998; Hacker et al., 2000). Symbols for the last three magma groups are listed in Fig. 3. The data for convergence rate and angle are after Lee and Lawver (1995). 
as having started $\sim 60 \mathrm{Ma}$ and any geologic events afterward as being "post-collisional". Then four principal magma suites postdating the India-Asia collision can be delineated as follows.

\subsection{Paleocene to Eocene arc magmatism in the southern Lhasa terrane}

Northward subduction of the Neo-Tethyan slab along the southern margin of Asia prior to the Indian indentation gave rise to an Andean-type magmatic arc, now exposed as the voluminous Gangdese batholith and Linzizong volcanic successions in the Lhasa terrane of southern Tibet (Fig. 1). Radiometric age data reported for the intrusive and volcanic rocks (Maluski et al., 1982; Schärer and Allègre, 1984; $\mathrm{Xu}$ et al., 1985; Coulon et al., 1986; Debon et al., 1986; Harris et al., 1988b; Copeland et al., 1995; Murphy et al., 1997; Miller et al., 1999; Harrison et al., 2000; Lee et al., 2001, 2003b; Wen et al., 2003) show that this arc magmatism began in the Early Cretaceous $(\geq 130 \mathrm{Ma})$ and lasted until the late Eocene $(\sim 40 \mathrm{Ma})$, with a presumable magmatic gap between $\sim 75$ and $60 \mathrm{Ma}$ (Fig. 2). The Cretaceous episode was more extensive, forming numerous granitic bodies throughout the Lhasa terrane, whereas the younger, post-collisional episode $(<60 \mathrm{Ma})$ appears to be restricted to the southern part of the Lhasa terrane. The widespread nature of the Cretaceous arc magmatism led some investigators (e.g., Coulon et al., 1986; Copeland et al., 1995) to suggest that low-angle or "flat" subduction, analogous to that observed in the modern Andes (cf. Allmendinger et al., 1997), may have occurred in southern Tibet before the India-Asia collision.

Of interest here, however, is the younger Paleocene to Eocene episode of the Gangdese batholith and Linzizong volcanic rocks that postdate the presumable magmatic gap (Fig. 2). Whereas the former consists dominantly of evolved lithologies such as diorites and granites (Tu et al., 1982; Debon et al., 1986; Harris et al., 1988a; Jiang et al., 1999; Harrison et al., 2000; Lee et al., 2001; Wen et al., 2003), the latter have more heterogeneous compositions ranging from basalt to rhyolite (Coulon et al., 1986; Pearce and Mei, 1988; Lee et al., 2003b). Similar to continental arc lavas worldwide, both the intrusive and volcanic rocks have calc-alkaline geochemical features although subalkaline rocks are occasionally observed (Coulon et al, 1986; Debon et al., 1986; Lee et al., 2003b). These rocks are generally sodium-rich and show crystallization trends marked by apparently lower alkali element contents than those of most post-collisional magmas on Tibet (Fig. 3a). There are limited $\mathrm{Sr}$ and $\mathrm{Nd}$ isotope data reported for the Gangdese granitoids and Linzizong volcanic rocks, with $\left({ }^{87} \mathrm{Sr} /{ }^{86} \mathrm{Sr}\right)_{\mathrm{i}} \approx 0.704-0.705$ and $\varepsilon_{\mathrm{Nd}}(\mathrm{T}) \approx+2$ to +4 (Harris et al., 1988b; Jiang et al., 1999; Wen et al., 2003, and unpublished data), which suggest significant involvement of a juvenile mantle component from the asthenosphere in the magma generation.

\subsection{Eocene to Oligocene magmatism in the Qiang- tang terrane}

This magma suite, first documented by Zhang et al. (1987), was previously assigned to occur in the interval between $\sim 40$ and $30 \mathrm{Ma}$ based on $\mathrm{Ar}-\mathrm{Ar}$ and $\mathrm{K}-\mathrm{Ar}$ age data from northeastern Tibet (Chung et al., 1998). Subsequent investigations (Deng, 1998; Ding et al., 1999, 2003; Roger et al., 2000; Deng et al., 2001; Wang et al., 2001; Xu et al., 2001; Li et al., 2002; Chu et al., 2004), however, found that this magma suite is both more widespread and older than the precedent acknowledgment. It is now recognized that the suite actually occurs over the entire Qiangtang terrane between $\sim 50$ and $30 \mathrm{Ma}$ (Fig. 2), if including the newly reported outcrops from the Banda Co ( $44 \mathrm{Ma})$ and Bamaoqiong Zong ( 39-44 Ma) (Deng, 1998), Yulinshan ( 29-31 Ma) (Ding et al., 1999, 2003), Dogai Coring ( 34$36 \mathrm{Ma}$ ) (Hacker et al., 2000), and Xialaxio ( $~ 50$

Fig. 3. (a) Plots of total alkalis versus silica (TAS) of post-collisional magmas from Tibet. Data sources include: Coulon et al. (1986), McKenna and Walker (1990), Arnaud et al. (1992), Turner et al. (1996), Chung et al. (1998, 2003), Deng (1998), Ding et al. (1999, 2003), Miller et al. (1999), Roger et al. (2000), Deng et al. (2001), Wang et al. (2001a), Williams et al. (2001), Xu et al. (2001), Zhao et al. (2001b), Li et al. (2002), and Chu et al. (2004). For comparison, the range of the Gangdese arc magmas is constructed using data of the Gangdese batholith and Linzizong volcanics (Coulon et al., 1986; Debon et al., 1986; Lee et al., 2003b; Wen et al., 2003). To better illustrate each magmatic group, plots of TAS (b, d, f) and $\mathrm{K}_{2} \mathrm{O}$ versus $\mathrm{Na}_{2} \mathrm{O}$ (c, e, g) are given separately. Rock suite classifications in the TAS and $\mathrm{K}_{2} \mathrm{O}-\mathrm{Na}_{2} \mathrm{O}$ plots are according to Le Maitre (2002) and Peccerillo and Taylor (1976), respectively. Symbols for magmas shown in this figure apply for Figs. 2-7. 
Ma) (Roger et al., 2000) areas. The emplacement of these Eocene to Oligocene magmas appears to have been accompanied by development of east-westtrending sedimentary basins (Fig. 1). Such a lava- basin association can be traced southeastward to regions around the Red River shear zone (Chung et al., 1997, 1998; Xu et al., 2001; Wang et al., 2001b; Li et al., 2002; Chu et al., 2004). Here, we divide this
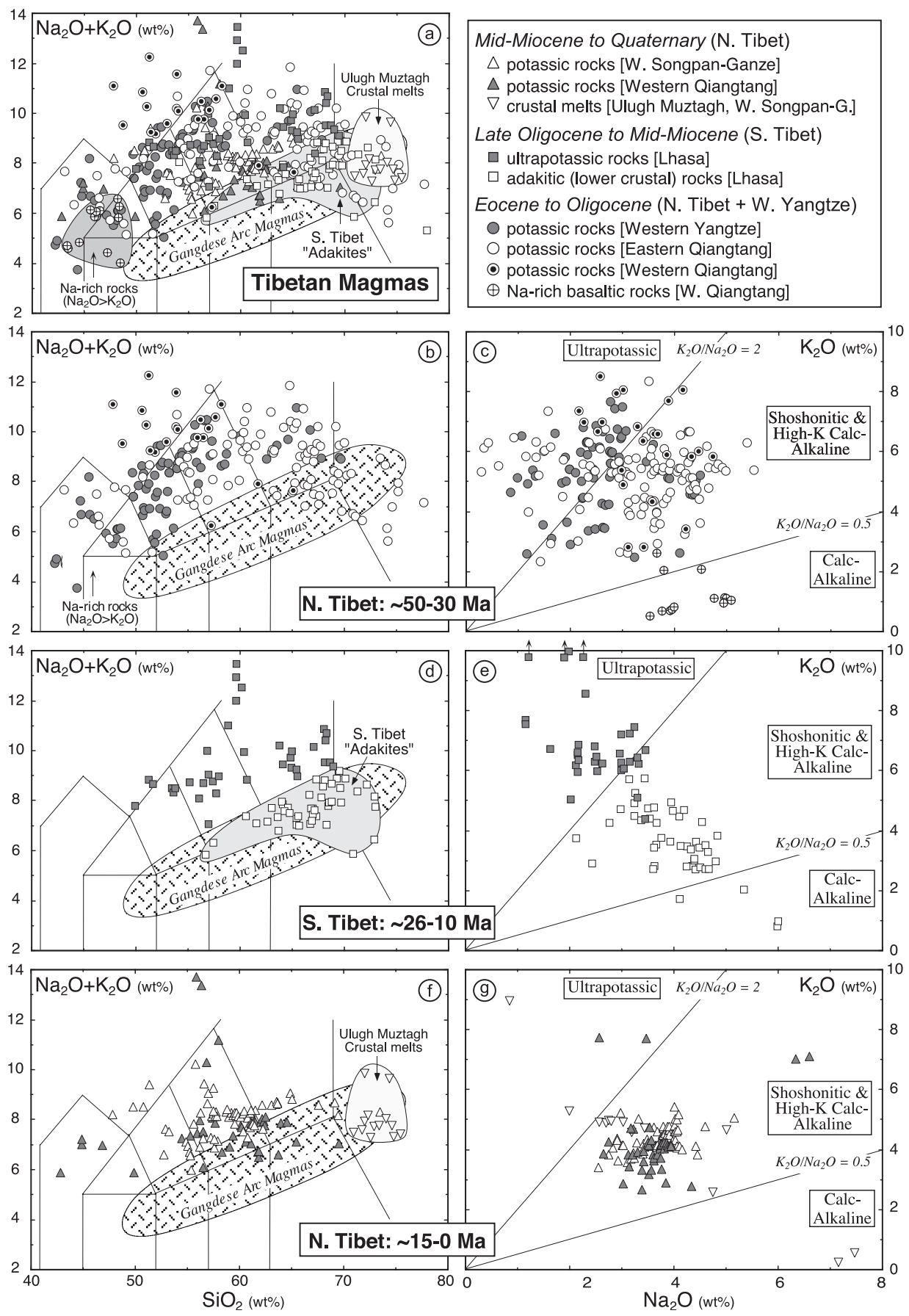
widely distributed magma suite that extends over $2000 \mathrm{~km}$ apart into three provinces, namely, from west to east, the western Qiangtang (including Banda Co, Yulinshan, and Bamaoqiong Zong areas from which good quality data are available), the eastern Qiangtang (Fenghuoshan, Nangqian, Xialaxio, Yulung, and Mangkang areas), and the western Yangtze (Dali and nearby localities) provinces.

Magmas of this stage occur as small-volume intrusive or extrusive bodies, ranging from mafic to felsic composition, which are characterized by high to very high alkali contents (Fig. 3b). They consist dominantly of shoshonitic and ultrapotassic rocks (Fig. 3c), coupled with subordinate sodium-rich basalts that are found in the Banda Co and nearby areas (Deng, 1998; Ding et al., 2003) in the western part of the Qiangtang terrane. The so-called "calc-alkaline granites" reported by Roger et al. (2000) from the Xialaxio area, with $\mathrm{SiO}_{2}$ contents of $\sim 65-75$ wt. $\%, \mathrm{Na}_{2} \mathrm{O} /$ $\mathrm{K}_{2} \mathrm{O}$ ratios of $\sim 0.8-1.3$, significant enrichments in the light rare earth (LREE; e.g., La up to $83 \mathrm{ppm}$ ) and large ion lithophile elements (LILE; e.g., $\mathrm{Rb} \approx 200$ $\mathrm{ppm}, \mathrm{Ba} \approx 1000 \mathrm{ppm} ; \mathrm{Th} \approx 50 \mathrm{ppm}$ ), and depletions in high field strength elements (HFSE), however, are actually shoshonitic rocks whose compositions are comparable to other felsic potassic rocks reported in the Qiangtang and western Yangtze provinces (Fig. 4a). These felsic rocks are often associated with high$\mathrm{MgO}$ (16-8 wt.\%) mafic rocks that have similar and even more enriched patterns in the primitive mantlenormalized, multielement variation diagram (Fig. 4a), implying an origin by small degrees of melting of enriched lithospheric mantle domains (Chung et al., 1998; Xu et al., 2001; Li et al., 2002; Ding et al., 2003; $\mathrm{Chu}$ et al., 2004). In contrast to the potassic mafic rocks that generally have $\mathrm{TiO}_{2}<1$ wt.\% (e.g., Xu et al., 2001), the Na-rich basalts from the Banda Co area that contain $\mathrm{SiO}_{2}$ of $\sim 45$ wt. $\%$ and $\mathrm{MgO}$ of $~ 8-6$ wt.\% are rich in titanium $\left(\mathrm{TiO}_{2} \approx 2.5-1.9\right.$ wt.\%) (Deng, 1998; Ding et al., 2003). These Na- and Ti-rich basalts are enriched in LREE (e.g., $\mathrm{La} \geq 40 \mathrm{ppm}$ ) and LILE, but mildly depleted in HFSE (Nb and Ta) (Fig. 4a). Their overall compositional characteristics appear to be similar to those of Paleocene $(\sim 60 \mathrm{Ma})$ alkali basalts from the Lagala area, south of the Yulinshan, the western Qiangtang (Ding et al., 2003) and Paleogene (67-46 Ma) basalts emplaced in the Tuyon basin, western Tian Shan (Sobel and Arnaud, 2000).

\subsection{Late Oligocene to mid-Miocene magmatism in the Lhasa terrane}

A new phase of magmatism that shows geochemical characteristics markedly different from those of the Gangdese batholith and Linzizong rocks occurred in the Lhasa terrane from the late Oligocene to middle Miocene (Fig. 2). This magma suite, first documented by Coulon et al. (1986) from the Majiang area, extends $\sim 1500 \mathrm{~km}$ across in the southern Tibetan plateau (Fig. 1). The outcrops occur either as smallvolume plugs or dike swarms which intrude or crosscut the Gangdese rocks, Linzizong volcanic successions, and/or underlying sedimentary formations; the dike swarms are often associated with the northsouth-striking normal faults (Williams et al., 2001). Two principal magma types were previously reported from this suite, namely, an ultrapotassic (or lamproitic when rocks have basic compositions) type and a "calcalkaline" type (Turner et al., 1996; Miller et al., 1999; Williams et al., 2001). The latter type, containing $\mathrm{Cu}$ and subordinate $\mathrm{Mo}-\mathrm{Au}$ deposits in certain localities (Qu et al., 2001), has been reexamined by Chung et al. (2003), which led the authors to identify the rocks as adakites from the active continental collision zone, a tectonic setting from which "collision-type" adakites are expected to occur as a result of melting of thickened lower crust (Rudnick, 1995; Kay and Kay, 2002). The Tibetan adakites consist of intermediate to felsic lithologies, with $\mathrm{SiO}_{2}$ contents ranging from $\sim 57$ to 73 wt. $\%$ and $\mathrm{Al}_{2} \mathrm{O}_{3}$ from $\sim 19$ to 15 wt.\% (Miller et al., 1999; Williams et al., 2001; Zhao et al., 2001b; Chung et al., 2003), lack a mafic member, and are Narich (Fig. 3d and e). They are further characterized by high $\mathrm{Sr}$ (up to $>1000 \mathrm{ppm}$ ), elevated $\mathrm{Sr} / \mathrm{Y}(\sim 250$ 40) and $\mathrm{La} / \mathrm{Yb}$ ratios, low $\mathrm{Y}(<10 \mathrm{ppm})$ and heavy rare earth elements (HREE; $\mathrm{Yb}<0.8 \mathrm{ppm}$ ), similar to the typical features of modern adakites from circumPacific subduction zones (Defant and Drummond, 1990; Martin, 1998).

In comparison with the adakites that have been recovered more widely from the Linzhi, Jiama, Majiang, Dajia Co, and Xungba areas (Fig. 1), the first type, ultrapotassic rocks appear to be confined to the west and have been so far found only in the Shiquanhe, Xungba, Dajia Co, and Wenbu areas (Turner et al., 1996; Miller et al., 1999; Williams et al., 2001; Chung et al., 2003; Ding et al., 2003). These 

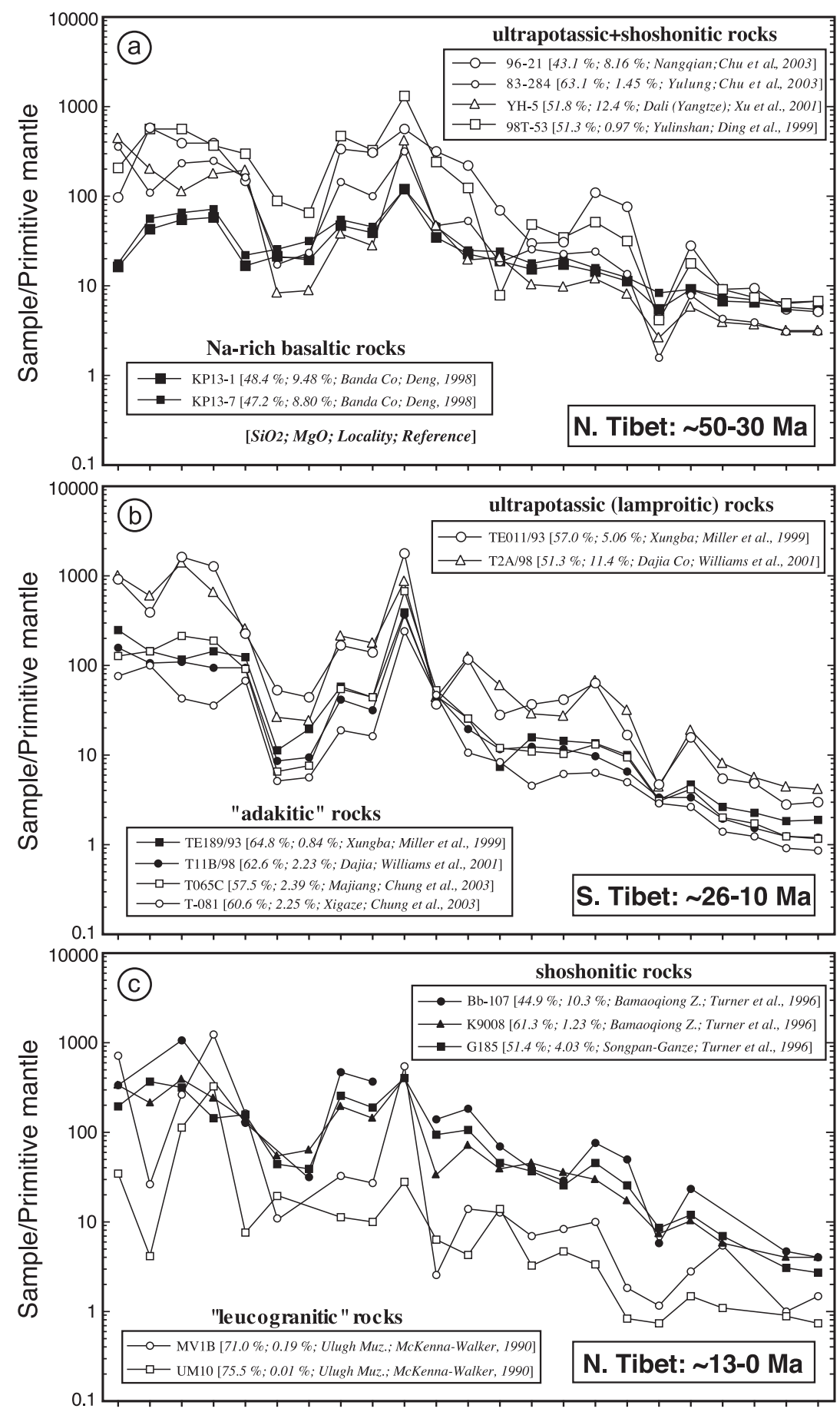

$\mathrm{Rb} \mathrm{Ba}$ Th U K Nb Ta La Ce Pb Sr Nd P Zr Hf SmEu Ti Tb Y Er Yb Lu

Fig. 4. Primitive mantle-normalized incompatible trace-element variation diagrams for representative samples from different post-collisional magma suites on Tibet. Data sources are the same as in Fig. 3. The normalizing values are from Sun and McDonough (1989). 
ultrapotassic lavas, marked by high total alkali contents (Fig. 3d) and $\mathrm{K}_{2} \mathrm{O} / \mathrm{Na}_{2} \mathrm{O}$ ratios (Fig. 3e), have heterogeneous compositions with a wide but semicontinuous $\mathrm{SiO}_{2}$ range from $~ 51$ to 69 wt.\% (Fig. 3d). In the multielement variation diagram (Fig. 4b), they show various amounts of enrichments in the LILE, LREE and $\mathrm{Pb}$, and depletions in HFSE, similar to the ultrapotassic and potassic rocks from the northern plateau (Fig. 4a and c). The two types of magmas of this stage occurred synchronously, with the ultrapotassic rocks being emplaced from $\sim 25$ to $13 \mathrm{Ma}$ and the adakites from $\sim 26$ to $10 \mathrm{Ma}$ (Fig. 2). Whereas the age data (Coulon et al., 1986; Arnaud et al., 1992; Miller et al., 1999; Williams et al., 2001; Chung et al., 2003; Ding et al., 2003; Spicer et al., 2003) define a rather wide magmatic period between $\sim 26$ and $10 \mathrm{Ma}$ (Fig. 2), dates $<13 \mathrm{Ma}$ have been reported only from Majiang (Coulon et al., 1986) and $>20 \mathrm{Ma}$ only from Xungba (Miller et al., 1999) and Linzhi (Chung et al., 2003) areas. We note that in the Chazi area, or grouped here as the Dajia Co area, Ding et al. (2003) reported a younger $\mathrm{Ar}-\mathrm{Ar}$ date of $8.2 \pm 0.5 \mathrm{Ma}$ for sanidine phenocrysts from an ultrapotassic rock and interpreted it to represent the age of volcanism, although two other dates on similar rocks from the same area both yielded $\sim 13 \mathrm{Ma}$, a result that appears to be more consistent with literature data (Williams et al., 2001). In the Majiang area, the youngest outcrops $(13-10 \mathrm{Ma})$ are now identified as adakites (Chung et al., 2003). We further point out that also from the Majiang area, the two "anomalous" Na-rich basalt samples (COUL 338 and 339), which were "conventionally" regarded as mid-Miocene in age without radiometric dating (Turner et al., 1996), should belong to the Paleogene Linzizong volcanic suite (Lee et al., 2003b).

\subsection{Mid-Miocene to Quaternary magmatism in the northern plateau}

Potassic magmatism occurred again in northern Tibet at $\sim 15 \mathrm{Ma}$ (Fig. 2) and appears to have become widespread and semicontinuous starting at 13 Ma or even later (Arnaud et al., 1992; Turner et al., 1993, 1996). Following the work by Turner et al. (1996), in which 51 out of 59 samples reported were from this magma suite, Deng (1998) published a comprehensive study in Chinese that not only sum- marizes previous results obtained by international collaborations but also presents new information from the western Qiangtang and Songpan-Ganze terranes. The data indicate that magmas of this stage vary from mafic to felsic but consist dominantly of intermediate lithologies (Fig. 3f). The rocks are generally shoshonitic in nature (Fig. 3g) and less K-rich than the Eocene to Oligocene potassic lavas emplaced also in the western Qiangtang terrane (Fig. $3 \mathrm{~b}$ and c). In contrast to the widespread occurrence of the older potassic magmas (Fig. 1), the younger ones have only been recovered from the western part of northern Tibet, i.e., in an area that broadly corresponds to the region under which high temperatures in upper mantle have been inferred from seismic data (McNamara et al., 1995). In the Ulugh Muztagh area, near the northern margin of the Songpan-Ganze terrane (Fig. 1), peraluminous leucogranites crop out as smallvolume intrusive lenses (Burchfiel et al., 1989; McKenna and Walker, 1990), which formed between $\sim 10$ and $4 \mathrm{Ma}$ (Fig. 2). These rocks have evolved compositions, with high silica contents and scattered $\mathrm{Na} / \mathrm{K}$ ratios (Fig. $3 \mathrm{f}$ and g), and show elemental and isotopic similarities to S-type granitoids; thus, workers suggested them to have been produced by remelting of upper crustal, primarily pelitic, source rocks (McKenna and Walker, 1990). Representative multielement variation patterns of the two types of magmas of this stage are given in Fig. 4c.

\section{Isotope systematics of Tibetan post-collisional magmatism}

Numerous $\mathrm{Sr}-\mathrm{Nd}-\mathrm{Pb}$ isotope data have been reported for the Tibetan post-collisional igneous rocks. In addition, $\mathrm{Re}-\mathrm{Os}$ isotopes have been measured for four Miocene potassic rock samples (three from the southern plateau and one from the north) by Schaefer et al. (2000) and Th-U disequilibria isotope data have been obtained for nine trachyandesites from NW Tibet with very young ages $(<120 \mathrm{ka})$ by Copper et al. (2002). A detailed review of these isotope results is not the goal of this paper; we simply plot here the initial $\mathrm{Sr}$ and $\mathrm{Nd}$ isotope ratios (Fig. 5) in the purpose of summarizing the main conclusions reached by previous workers. Then combined with information from the multielement variation patterns (Fig. 4) and plots of 


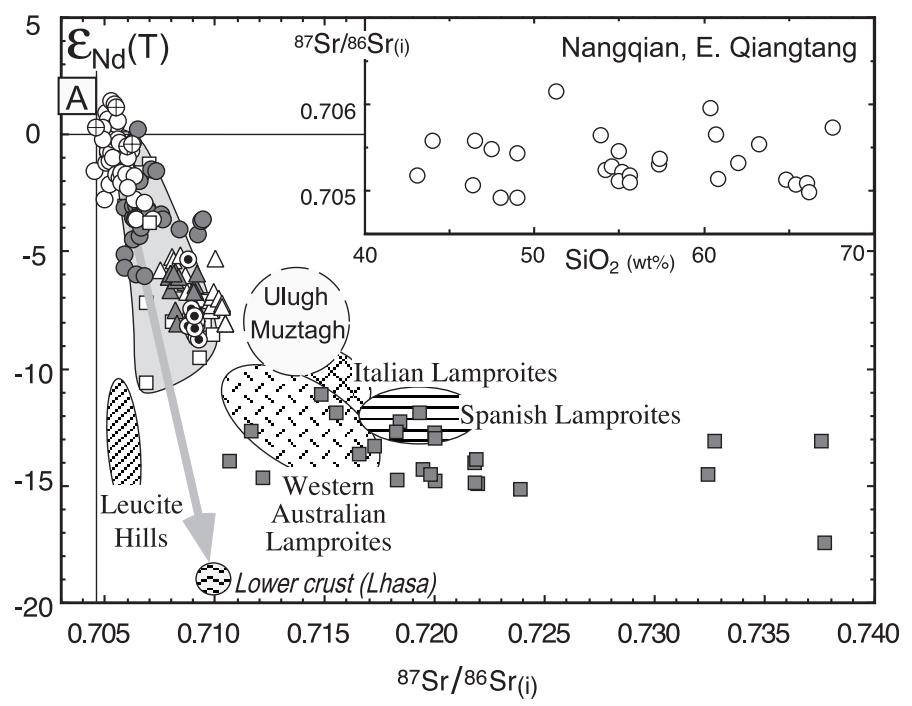

Fig. 5. Correlation diagram of initial Nd and Sr isotope ratios. Data sources include McKenna and Walker (1990), Turner et al. (1996), Deng (1998), Ding et al. (1999, 2003), Miller et al. (1999), Roger et al. (2000), Deng et al. (2001), Wang et al. (2001a), Williams et al. (2001), Xu et al. (2001), Zhao et al. (2001b), Li et al. (2002), and Chu et al. (2004). The lower crust component of the Lhasa terrane proposed by Miller et al. (1999) is also shown. Inset illustrates the Sr isotope uniformity observed in the heterogeneous (mafic to felsic) Paleogene potassic lavas from the Nangqian basin (data from Chu et al., 2004). Fields of several important lamproite provinces worldwide shown for comparison purpose are after Nelson (1992).

$\mathrm{La} / \mathrm{Yb}$ versus $\mathrm{Sr}$ isotope ratios (Fig. 6), compositional variations in the magma source regions involved in the melt generation are addressed. Note that in the plots,
Paleogene rocks produced in the last phase of Gangdese magmatism, whose isotope characteristics have been described above, are not included.

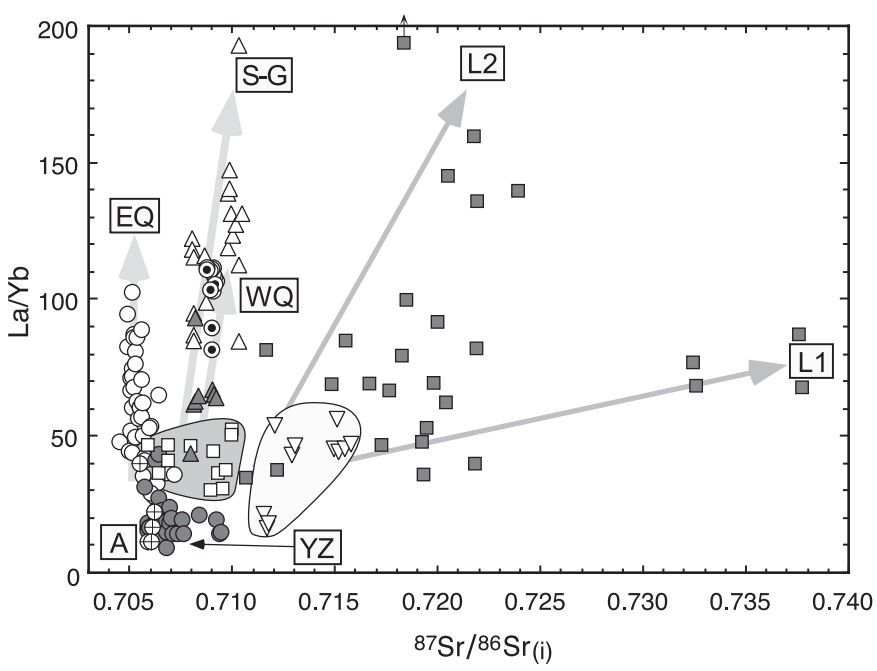

Fig. 6. Plots of $\mathrm{La} / \mathrm{Yb}$ versus initial $\mathrm{Sr}$ isotope ratios; various magma evolution trends imply distinguishable enriched mantle domains to be present in the lithosphere beneath different terranes. EQ=Eastern Qiangtang; WQ=Western Qiangtang; YZ=Yangtze; L1 and L2=Lhasa Components 1 and 2, respectively; and $\mathrm{S}-\mathrm{G}=$ Songpan-Ganze. Symbol A marks the asthenospheric domain inferred from Paleogene Na-rich calc-alkaline lavas from the western Qiangtang terrane. Data sources are same as in Fig. 5. 
The post-collisional magmas on Tibet exhibit heterogeneous $\mathrm{Sr}$ and $\mathrm{Nd}$ isotope ratios not only among different magma provinces but also within a single suite (Fig. 5). Following the notion of Turner et al. (1996), the Tibetan potassic lavas which are volumetrically limited but geographically most widespread have been commonly considered as small-degree melts from a metasomatized, and perhaps veined, garnet peridotite source that contain phlogopite (and/ or amphibole) and lie within the lithospheric mantle (Chung et al., 1998; Deng, 1998; Miller et al., 1999; Williams et al., 2001; Xu et al., 2001; Li et al., 2002; Chu et al., 2004). The isotopic heterogeneity, exemplified by the Eocene to Oligocene ultrapotassic/ potassic rocks from the western and eastern Qiangtang and western Yangtze provinces (Figs. 5 and 6), which delineate markedly different ranges, is therefore a manifestation of compositional heterogeneity in lithospheric mantle domains that may have undergone different and complex enrichment histories. Such heterogeneity is best demonstrated by the ultrapotassic lavas from the Lhasa terrane, which show the highest initial $\mathrm{Sr}$ and lowest $\mathrm{Nd}$ isotope ratios (Fig. 5). In addition, in the $I_{\mathrm{Sr}}$ versus $\mathrm{La} / \mathrm{Yb}$ plots (Fig. 6), at least two evolving trends may be identified for these rocks recovered from different parts of the Lhasa terrane. For the mid-Miocene to Quaternary potassic rocks in northern Tibet, those from the western Qiangtang terrane have isotopic and elemental $(\mathrm{La} /$ $\mathrm{Yb}$ ) features corresponding to those of the Paleogene rocks, while those from the western Songpan-Ganze have similar $\mathrm{Sr}$ and $\mathrm{Nd}$ isotope compositions (Fig. 5) but more enriched $\mathrm{La} / \mathrm{Yb}$ ratios (Fig. 6). The majority of these potassic lavas are composed of intermediate to felsic lithologies which have been generally interpreted as products of various amounts of fractional crystallization from associated mafic melts without significant crustal assimilation (Turner et al., 1996; Chung et al., 1998; Deng, 1998; Miller et al., 1999; Chu et al., 2004). This interpretation can be demonstrated by an example from the Nangqian basin, in which Paleogene potassic rocks with a wide silica range ( 43-68 wt.\%) show $\mathrm{Sr}$ isotope ratios that remain almost unchanged over the whole spectrum of magma compositions (Fig. 5, inset).

The Na-rich basalts from the Banda Co area and the two suites of crustal melts that were emplaced in different parts of the Tibetan plateau at different times have distinctive isotopic signatures. The initial $\mathrm{Nd}$ and $\mathrm{Sr}$ isotope ratios of the Na-rich basalts, with $\varepsilon_{\mathrm{Nd}}(\mathrm{T}) \approx+1$ to $-1 ; I_{\mathrm{Sr}} \approx 0.7046-0.7062$ (Deng, 1998; Ding et al., 2003), plot in a limited range that is among the highest and lowest, respectively, in the Tibetan magmas (Fig. 5). The adakites from southern Tibet, by contrast, exhibit a larger variation in $\mathrm{Nd}$ and $\mathrm{Sr}$ isotope compositions $\left[\varepsilon_{\mathrm{Nd}}(\mathrm{T}) \approx 0\right.$ to -11 ; $I_{\mathrm{Sr}} \approx 0.706-0.710$; Miller et al., 1999; Williams et al., 2001; Zhao et al., 2001b; Chung et al., unpublished data], which differ markedly from those of the associated ultrapotassic lavas and had therefore led Miller et al. (1999) to invoke a substantial involvement of lower crustal materials of the Lhasa terrane in the magma generation. $\mathrm{Nd}$ isotope data are not yet available for the Ulugh Muztagh leucogranites, but their range may be schematically denoted (Fig. 5) in terms of the high $\mathrm{Sr}$ isotope ratios $\left(I_{\mathrm{Sr}} \approx 0.711-\right.$ 0.713 ) reported by McKenna and Walker (1990).

\section{Use and abuse of geochemical constraints on magma generation}

Changes in the tectonic setting that may involve changes in geodynamic processes are often recorded by changes in compositions of the resultant magmas. Therefore, together with age constraints, geochemical characteristics of the post-collisional magmatism on Tibet have been widely used, and/or abused, to explore the Tibetan tectonic evolution as well as the plateau's formation. Comments on the abuses are necessary and will be given briefly in the following along with our preferred interpretations.

\subsection{The cessation of the Gangdese arc magmatism}

Whereas most, if not all, workers consider the Gangdese arc magmatism to have ceased at $\sim 40$ Ma, Harrison et al. (2000) argued that the magmatism lasted longer, at least to $\sim 30 \mathrm{Ma}$, based on their study of a deformed granitoid intrusion (the Yaja granodiorite) from the hanging wall of the "Gangdese Thrust" in the Zedong area (south of the Jiama village; Fig. 1), southeastern Tibet. With some arguments such as "the major and trace element compositions of the Yaja granodiorite strongly resemble previous results from the Gangdese batholith" (Harri- 
son et al., 2000; p. 19220), these authors assumed the geodynamic processes responsible for genesis of the pre-collisional Gangdese batholith to be similar to those that produced melting later when the IndiaAsia collision was well underway. Furthermore, they advocated that the 30 Ma Yaja granodiorite does not represent the youngest arc-type magmatism in the Gangdese belt that should include the Miocene high$\mathrm{K}$ calc-alkaline rocks emplaced in the Majiang area (Coulon et al., 1986) and southwestern Tibet (Miller et al., 1999). Hence, they regarded the Gangdese magmatism as a poor indicator of the termination of subduction of oceanic lithosphere and speculated that there existed mechanism(s) that may have been operating continuously, from pre- to post-collisional, in producing the "calc-alkaline, arc-type magmatism" widespread in southern Tibet throughout the Tertiary (Harrison et al., 2000; p. 19228).

There are flaws in the above arguments. First, according to the major- and trace-element data reported by Harrison et al. (2000; Table 2, p. 19217), the geochemical characteristics of the Yaja granodiorite do not resemble those of the Gangdese batholith but mimic those of the late Oligocene-Miocene adakites emplaced in nearby regions such as those from the Jiama ( 17-13 Ma) and Linzhi ( 26 Ma) areas (Fig. 1). Besides, as described earlier, all the "high-K calc-alkaline rocks" which occur widely in southern Tibet (Coulon et al., 1986; Miller et al., 1999; Williams et al., 2001) have geochemical systematics similar to modern adakites. The Yaja granodiorite samples exhibit high $\mathrm{Sr}(\sim 600-1160 \mathrm{ppm})$ and strongly fractionated REE patterns marked by very low HREE contents $(\mathrm{Yb}<1.0 \mathrm{ppm} ; \mathrm{Y} \approx 9-11 \mathrm{ppm})$, thus possessing high $\mathrm{Sr} / \mathrm{Y}$ and $\mathrm{La} / \mathrm{Yb}$ ratios that are typical and discriminating features of adakitic rocks. It is also indicative of melting of a mafic source, where garnet and/or amphibole are residual phases, in the lower portion of thickened crust of the Lhasa terrane (see below). In our view, only after more detailed analyses, including reassessment of the existence of the "Gangdese Thrust" (cf. Aitchison et al., 2003), can the geological meaning of the Yaja intrusion be understood more comprehensively. Based on the above evaluation, we believe that the Gangdese and related magmatism ceased no later than $\sim 40 \mathrm{Ma}$ and since that time igneous rocks of calc-alkaline geochemical affinities have not been emplaced in southern Tibet.

\subsection{Eocene to Oligocene magmatism in the northern and northeastern plateau}

Roger et al. (2000) argued that there is an Eocene calc-alkaline magmatic belt, which may have marked a former northern border of the Tibetan plateau, and proposed south-directed subduction of the Asian mantle lithosphere along one of northern Tibet's Mesozoic sutures. This idea of "continental subduction", by analogy with the present-day underthrusting of the Indian lower continental lithosphere beneath the Himalayas and southern Tibet (Owens and Zandt, 1997; Kosarev et al., 1999), has been further developed (Tapponnier et al., 2001) and adopted to interpret the seismic images from northeastern Tibet (Kind et al., 2002) and the Cenozoic volcanism in Tibet (Ding et al., 2003). Moreover, based on works from the eastern margin of the Tibetan plateau, Wang et al. (2001a) concluded that the geochemical data of the Paleogene igneous rocks they studied suggest an origin by continental subduction. This notion led the authors to propose a tectonomagmatic evolution mod$\mathrm{el}$, in which the proposed continental subduction is linked to regional crustal deformation such as transpression and transtension transition along the Red River strike-slip fault system. Under this framework, the Nangqian and other Paleogene sedimentary basins in northeastern Tibet are believed to have formed in a contractional environment where their narrow width is a result of thrust spacing (Horton et al., 2002).

The Eocene calc-alkaline magmatic belt envisioned by Roger et al. (2000), however, did not exist. Few magmas produced in this stage are calc-alkaline in nature; instead, the majority are of shoshonitic and ultrapotassic compositions with $\mathrm{K}_{2} \mathrm{O} / \mathrm{Na}_{2} \mathrm{O}>1$ (Fig. $3 \mathrm{c})$. Even if the alleged "south-directed continental subduction" did happen, it would have terminated rather than initiated the magmatism, as did the northward underthrusting of the Indian lithosphere which caused ultrapotassic and adakitic magmatism in southern Tibet to cease $\sim 10 \mathrm{Ma}$ (see below). This is simply because "subduction" of the continental lithospheric mantle, which is refractory and essentially dry (Menzies, 1990), is unable to produce subduction zone magmas that require significant amounts of water that can be released by oceanic slab dehydration reactions (Tatsumi and Eggins, 1995). The igneous rocks investigated by Wang et al. (2001a) cannot 
provide evidence for (or against) the presence of continental subduction. The widespread occurrence of high-Mg potassic lavas from the Bamaoqiong Zong (Deng, 1998), Nangqian (Ding et al., 1999; Wang et al., 2001a; Chu et al., 2004), Mangkang (Chung et al., 1998), Dali (Xu et al., 2001; Li et al., 2002), and Ailao Shan (Chung et al., 1998; Wang et al., 2001a) regions clearly indicates an origin by melting of enriched lithospheric mantle domains. This does not support the argument that the magmatism was controlled by crustal deformation, but rather points to the involvement of dynamic mantle processes. Moreover, the emplacement of potassic magmas associated with basin development was not confined to the principal strike-slip fault zones around the eastern Tibetan plateau. The basin-magmatism association occurred more extensively in the western Qiangtang province (Fig. 1), in which large sedimentary basins show a dominant east-west elongation that implies regional north-south extension.

\subsection{Late Oligocene to mid-Miocene magmatism in the southern plateau}

Miller et al. (1999) discussed two possible mechanisms, i.e., convective removal of the lower lithosphere and breakoff of the Neo-Tethyan slab, which may have caused partial melting of metasomatized lithospheric mantle to form the ultrapotassic magmatism in the Lhasa terrane. Although the slab breakoff scenario has been adopted by Mahéo et al. (2002) for the magma generation in southwestern Tibet and Karakorum, Williams et al. (2001) argued with a larger scale for the lithospheric removal. The latter involves the dissipation of potential energy that would cause further consequences such as the uplift and extension of the Tibetan plateau (cf. Molnar et al., 1993). The work of Chung et al. (2003) reinforces the point by Williams et al. (2001) that the widespread occurrence of post-collisional magmatism in the Lhasa terrane (Fig. 1) indicates that these smallvolume igneous activities are regional phenomenon. This further supports the hypothesis that calls for removal of the thickened lithospheric root underneath southern Tibet (see below). In this sense, the ultrapotassic lavas and adakites are interpreted as melts of the metasomatized lithospheric mantle and mafic lower crust of the Lhasa terrane, respectively.
The occurrence of adakitic rocks from southern Tibet suggests that there was a thickened crust $(>50$ $\mathrm{km}$ ) in the region and that its lower part consisted of mafic eclogite and/or garnet amphibolite which melted because of a major thermal perturbation caused by removal of the Lhasa lithospheric keel (Chung et al., 2003). Reasons why the subducted Neo-Tethyan slab was not source for the Tibetan adakites include (1) the adakites show "enriched" $\mathrm{Nd}$ and $\mathrm{Sr}$ isotope ratios (Fig. 5) which indicate an origin by melting of continental rather than oceanic crustal material and (2) the Neo-Tethyan slab is more likely to have been detached from the orogenic system and then moved into the deep mantle in Eocene time (Kohn and Parkinson, 2002; DeCelles et al., 2002). This line of reasoning implies that a significant thickening of the Lhasa lithosphere, mostly in its lower crust and mantle (cf. Chung et al., 2003), took place between the beginning of the adakite magmatism $(\sim 26 \mathrm{Ma})$ and the waning of the Linzizong volcanism $(\sim 40$ $\mathrm{Ma}$ ), provided that the calc-alkaline nature and high contents of HREE of the Linzizong volcanic rocks (Lee et al., 2003b) suggest arc magma generation from the mantle wedge with a "normal" ( $\sim 30-35$ $\mathrm{km})$ crustal thickness.

\subsection{Mid-Miocene to Quaternary magmatism in the northern plateau}

Magmas of this stage were divided by Yin and Harrison (2000) into a "highly potassic group" and a "calc-alkaline group", with the former group supposedly being distributed mainly in the western SongpanGanze province and the latter group in the western Qiangtang province. Such a division, however, is arbitrary and misleading. The igneous rocks from the two provinces (Fig. 3f and g) are both composed of mafic to felsic lithologies that plot into the shoshonitic and high-K calc-alkaline field and contain incompatible trace-element characteristics (Fig. 4c) and $\mathrm{Sr}-\mathrm{Nd}$ isotope systematics (Fig. 5) indistinguishable from each other. Some workers (Yin and Harrison, 2000; Kapp et al., 2000) advocated that the deeper crust of much of the Qiangtang terrane is composed of Triassic melange-flysch complexes. Moreover, they proposed that this "hydrous" continental crust was "subducted" to mantle depths by Cenozoic thrusting along the Fenghuoshan-Nangqian fold-and-thrust system. De- 
hydration reactions thus caused may have released large quantities of free water that, in turn, triggered partial melting to form the widespread volcanism in northern Tibet (cf. Yin and Harrison, 2000). This model that does not account for the high-temperature phenomena in the upper mantle (McNamara et al., 1995; Huang et al., 2000); it appears to be at odds with the deep crustal xenolith evidence reported by Hacker et al. (2000), which suggests the presence of hot, dry crust at depths of $\sim 30-50 \mathrm{~km}$ underneath the central Qiangtang terrane.

We reiterate here an important but poorly explored feature of the potassic volcanism in northern Tibet; that is, the volcanism was renewed only in the western part, in contrast to the widespread occurrence of the preceding post-collisional magmatism in the northern plateau. This implies an east-west difference in the evolution of the lithosphere under the Qiangtang and Songpan-Ganze terranes since at least mid-Miocene time. Therefore, the anomalous high temperatures in the upper mantle beneath northern Tibet, linked genetically with the renewed igneous activity (Turner et al., 1996), should be confined to the western part of the northern Tibetan plateau. Thus, the apparent eastward expansion of the high-temperature upper mantle observed by McNamara et al. (1995) may be an overmeasure that awaits careful reevaluation (Kao, H., 2001, personal communication). It could also be a result of the eastward mantle flow that manifests a hot and weak upper mantle beneath northern Tibet which is being squeezed and sheared between the advancing Indian lithosphere to the south and the Qaidam and Tarim lithospheres to the north and west (Huang et al., 2000).

\section{An integrated model for Tibetan tectonomagmatic evolution}

The spatial-temporal and geochemical variations we have described above suggest that the thermal structure of the Tibetan deep lithosphere must have evolved. Here, we propose a new and self-consistent tectonomagmatic evolution model, shown graphically in Fig. 7 via time series of north-south sections along $\sim 90^{\circ} \mathrm{E}$ across the Tibetan plateau, that intends to link the magmatic features with deep lithosphere dynamics. The last profile (Fig. 7e) delineating the current Tibetan structure was constructed after the INDEPTH results (e.g., Owens and Zandt, 1997; Kosarev et al., 1999; Tilmann et al., 2003), whereas the remaining profiles (Fig. 7a-d) present scenarios that match constraints imposed by the spatial-temporal and geochemical variations observed in the post-collisional magmatism along with relevant geological and geophysical data. These profiles, nevertheless, should be regarded as general pictures for the large-scale evolution of Tibet, but not applied to the eastern and western Himalayan Syntaxes that have more complex geological records (cf. Zeitler et al., 2001) and seismic tomography images (Van der Voo et al., 1999), which require specific interpretations.

\section{1. $65-45 \mathrm{Ma}$}

To interpret two "anomalous" phenomena observed prior to the India-Asia collision, i.e., the Gangdese magmatic gap and the sudden rise in the convergence rate (Fig. 2), rollback of a flatly subducting Neo-Tethyan slab is proposed to have taken place during $\sim 70-60 \mathrm{Ma}$. This would have enhanced gravitational pull of the slab, which would not only account for the increase in the convergence rate but also facilitate the dragging down of the attached Indian continental lithosphere to greater depths (Chemenda et al., 2000). The latter process explains why there was a general lack of contraction and shortening in the upper crustal levels along the Gangdese arc and elsewhere in the Lhasa terrane in the Paleogene (England and Searle, 1986; Fielding, 1996), despite a substantial indentation of the Indian continent during this time. The slab rollback would have been accompanied by a southward migration of the asthenospheric convection beneath Tibet, which should have significantly enhanced the asthenospheric corner flow and changed the thermal structure of the mantle wedge. Thus, the final phase of Gangdese arc magmatism was characterized by a dominant asthenospheric mantle source component. Furthermore, these processes could have been responsible for initiating a "back-arc" extension setting in the Qiangtang terrane that casued the east-west-trending sedimentary basins and associated magmatism. The magmatism started with Na-rich basalts in the Paleocene and changed to potassic and ultrapotassic compositions from the Eo- 
cene to Oligocene. Similar scenarios involving slab rollback, back-arc extension, basin formation, and magmatic activity have been widely postulated for the evolution of the Mediterranean-Carpathian orogenic system (e.g., Chalot-Prat and Girbacea, 2000;
Wortel and Spakman, 2000), where breakoff of the subducted oceanic slabs has been considered a natural consequence in the terminal stage of subduction owing to gravitational settling (Wortel and Spakman, 2000).

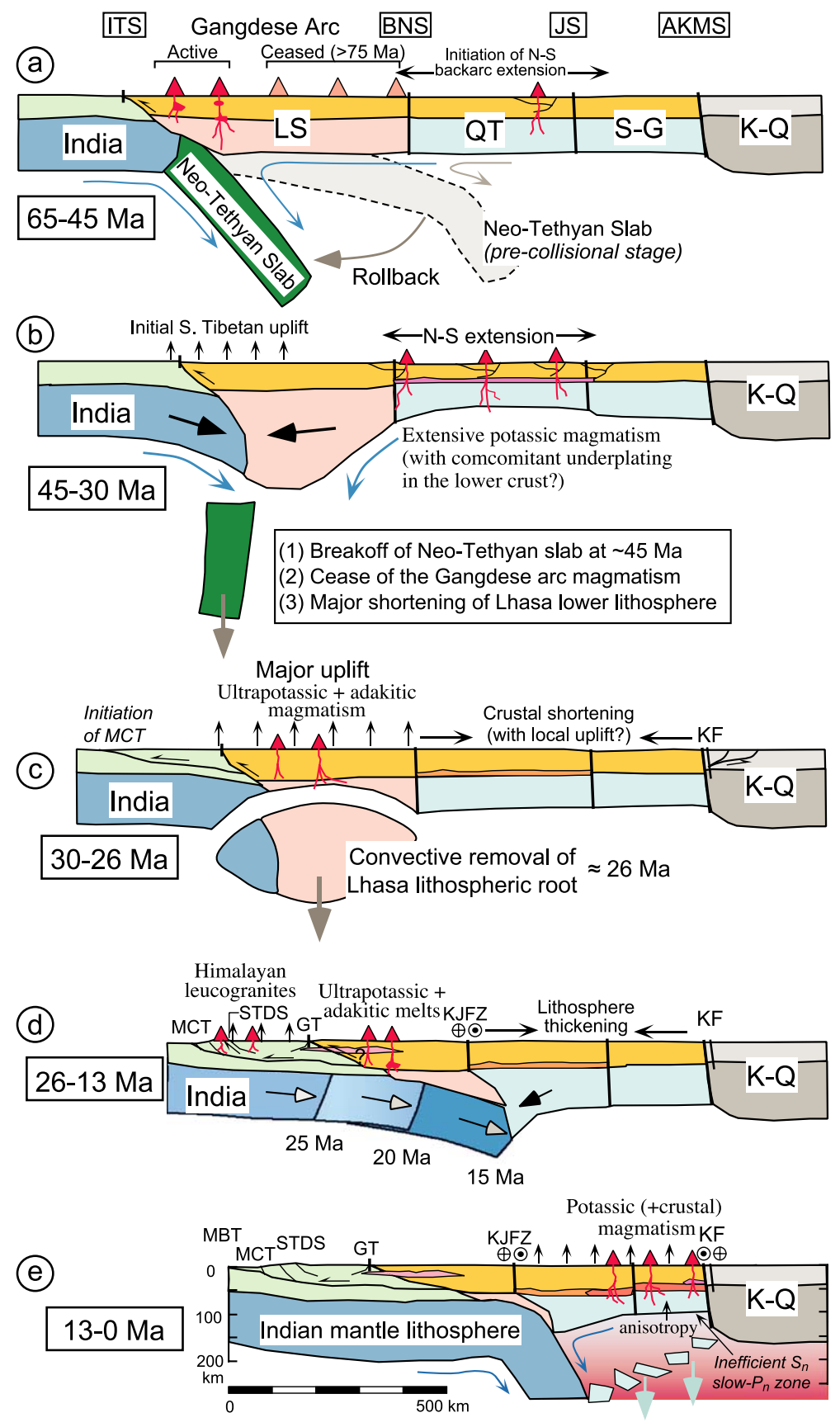




\section{2. $45-30 \mathrm{Ma}$}

The Neo-Tethyan oceanic slab is suggested to have detached from the Indian continental lithosphere at $\sim 45 \mathrm{Ma}$, in accordance with the Himalayan metamorphic record (e.g., Kohn and Parkinson, 2002; DeCelles et al., 2002) and the onset of the IndiaAsia "hard collision" (Fig. 2). This slab breakoff would have led to cessation of the Gangdese arc magmatism and a substantial amount of topographic uplift, similar to that proposed for the modern Central America example (Rogers et al., 2002). Thus, a high but relatively narrow mountain range, akin to the Altiplano-Puna plateau of Central Andes (cf. Allmendinger et al., 1997), may have already existed since the Middle Cretaceous in where southern Tibet is now located (England and Searle, 1986; Fielding, 1996). The breakoff, which eliminated slab pull, would have prevented the Indian cratonic mantle lithosphere from moving further downward because it is more refractory and intrinsically more buoyant than the Asian mantle lithosphere (Fielding, 1996). Without anywhere for the Indian mantle lithosphere to go, the continuous northward impingement of India should have given rise to significant contraction in the lower part of the Lhasa lithosphere that may have been thermally weakened and "softened" by the previous arc magmatism (Thompson et al., 2001). While this could have greatly thickened the Lhasa lithospheric lid, it would not have caused major shortening in the upper crustal levels. In the meantime, in where is now the northern and northeastern Tibetan plateau, a different style of tectonism involving the "back-arc" lithospheric extension that began in early Tertiary time was operating. This extensional event, however, seems to have been diminished in the Oligocene when the magmatism in the region changed its compositions from Na-rich basalts to potassic and ultrapotassic, implying a gradual decrease in degrees of partial melting in the mantle source. It is noted that the potassic lavas have major- and trace-element characteristics comparable to those of modern backarc shoshonitic rocks from the central Andes (e.g., Kay et al., 1994; Barragan et al., 1998). A similar tectonic scenario of slab rollback and back-arc extension has been proposed (Bertrand et al., 2001; Morley, 2001) for the mid-Tertiary rift basin formation in the Shan-Thai-Malay of Southeast Asia.

\section{3. $30-26 \mathrm{Ma}$}

The Indian collision eventually caused the Qiangtang terrane to switch from an extensional to compressional regime in Oligocene time. This is borne out by the waning and then cessation of the potassic magmatism and the development of a major sedimentary hiatus in the Hoh Xil basin (Liu et al., 2000; Liu and Wang, 2001), both around $\sim 30 \mathrm{Ma}$. It is hence proposed that regional crustal shortening, perhaps with concomitant topographic uplift (Liu and Wang, 2001), began at this time in the area far behind the collision front. In southern Tibet, we follow previous studies (Miller et al., 1999; Williams et al., 2001) in adopting the convective lithospheric thinning model (Molnar et al., 1993; Platt and England, 1994). Under the framework of this model, the ultrapotassic and adakitic magmas are interpreted as partial melts of the metasomatized lithospheric mantle and eclogitized lower crust, respectively, of the Lhasa terrane owing to a significant thermal perturbation caused by removal of the lower part of the Lhasa lithospheric mantle. The beginning of magmatism, i.e., $\sim 26 \mathrm{Ma}$ for the adakites from the Linzhi area and $\sim 25 \mathrm{Ma}$ for the ultrpotassic lavas from the Xungba area, should therefore coincide with, or slightly postdate, the lithospheric removal event (Williams et al., 2001). We hence

\footnotetext{
Fig. 7. Stages of Tibetan plateau evolution illustrated by the $90^{\circ} \mathrm{E}$ north-south cross sections. (a) $65-45$ Ma: Marked by rollback of the formerly flatly subducted Neo-Tethyan slab and initiation of the north-south extension in the back-arc region. The Gangdese arc magmatism halted when the slab was rolling back. (b) 45-30 Ma: Detachment of the Neo-Tethyan slab and onset of the "hard collision" particularly in the lower part of the India and Lhasa lithospheres. (c) 30-26 Ma: Removal of the gigantic Lhasa lithospheric mantle leading to the uplift and formation of the southern Tibetan plateau. (d) 26-13 Ma: Northward underthrusting of the Indian mantle lithosphere associated with Himalayan tectonomagmatism. The ultrapotassic and adakitic magmatisms, resulting from thermal perturbation owing to the loss of thickened Lhasa lithospheric root, ceased by the underthrusting. (e) 13 Ma to the present: "Diffused" destruction of the lower part of the lithospheric mantle beneath the Qiangtang and Songpan-Ganze terranes to reactivate the potassic magmatism and raise the northern plateau. This cross section is largely based on the present-day lithospheric profile of Tibet proposed by Owens and Zandt (1997). The seismic data suggestive of hightemperature features in the mantle under northern Tibet are from McNamara et al. (1995), Huang et al. (2000) and Holt (2000).
} 
suggest that in southern Tibet, the lower part of the Lhasa lithosphere was removed in the late Oligocene. Given that the collision-thickened Lhasa lithosphere may have reached to a thickness as great as $\sim 300$ $\mathrm{km}$ (Fielding, 1996), the lithospheric keel must have been almost completely removed to let the more buoyant Indian mantle lithosphere start moving northward. Such a massive loss of the lithosphere is considered the key process that caused elevation of southern Tibet or the entire Lhasa terrane. Our interpretation, invoking two separate detachments of the Neo-Tethyan slab and thickened Lhasa lithosphere occurring at $\sim 45$ and $26 \mathrm{Ma}$, respectively, is in general agreement with the seismic tomographic image along a corresponding north-south cross section (Van der Voo et al., 1999; Fig. 4c). The latter detachment was broadly synchronous to, and thus perhaps responsible for, the onset of major Himalayan tectonomagmatism along the Main Central Thrust and South Tibetan Detachment System (cf. Hodges, 2000; Guillot and Allemand, 2002).

\section{4. $26-13 \mathrm{Ma}$}

In the Lhasa terrane, the loss of its lithospheric root and replacement by hotter asthenosphere would have greatly raised the geothermal condition, which led to generation of the ultrapotassic magmas of this stage from the remnant lithospheric mantle and the adakites from the mafic lower part of the Lhasa crust that had been thickened and hence eclogitized in its deeper levels after the slab breakoff (Chung et al., 2003). These magmatic activities ceased at $\sim 13-10 \mathrm{Ma}$ as a result of northward underthrusting of the cold Indian mantle lithosphere, which should have reached the Bangong-Nujiang suture zone by this time and thus shut off the heat source from the asthenosphere. By contrast, the early to middle Miocene evolution in northern Tibet was marked by a major episode of crustal and lithospheric shortening (Liu et al., 2000) that we interpret as a consequence of the squeeze between the northward advancing Indian mantle lithosphere, which would have largely deformed and pushed the Lhasa lower lithosphere, and the backstop of a rigid continental lithosphere beneath the Qaidam (Zhu and Helmberger, 1998) and Tarim (Huang et al., 2000) basins. This could have been facilitated by the existence of a thin, relatively weaker, lithosphere in the Qiangtang and Songpan-Ganze regions, which formed during the Eocene to Oligocene "back-arc" extension associated with potassic magmatism. The latter might have caused magmatic underplating around the Moho (Fig. 7b), a process that is capable of further weakening the deep lithosphere. The squeezing may have not only led to lithospheric thickening and its subsequent destruction (see below) but also continued to the present time, which gave rise to the strong seismic anisotropic fabric (Zhang and Karato, 1995) observed in the lithospheric mantle beneath the region (McNamara et al., 1995; Huang et al., 2000).

\section{5. $13 \mathrm{Ma}$ to the present}

The tectonic setting of northern Tibet was transformed to an east-west extensional environment beginning at $\sim 13 \mathrm{Ma}$, as shown by the synchronous onset of renewed potassic volcanism (Fig. 2) and north-south-striking normal faulting (Blisniuk et al., 2001). It is noted that structural geology data obtained by Blisniuk et al. (2001) from the central Qiangtang lend direct evidence to such a tectonic transformation. By analogy with the southern plateau where removal of thickened Lhasa lithospheric root reflects the dissipation of potential energy (in excess of that can be supported by convergent forces; Houseman et al., 1981), the squeezing between the northward advancing Indian and the resisting Qaidam and Tarim lithospheres would have resulted in thickening and subsequent destruction of the lower portion of the lithosphere in northern Tibet owing to gravitational instability (cf. Huang et al., 2000; for details). This lithospheric destruction, via a complicated "diffuse" fashion (Kosarev et al., 1999) or even coupled with south-directed underthrusting of Asian lithosphere (Kind et al., 2002), is argued to have taken place at $\sim 13 \mathrm{Ma}$ when the Indian mantle lithosphere had reached the region underneath the Bangong-Nujiang suture zone. Consequently, the western Qiangtang and Songpan-Ganze lithospheres began to founder and downwelling of the Indian lithosphere occurred beneath central Tibet (Tilmann et al., 2003). It is further suggested that the lithospheric destruction played a crucial role in raising the topography and initiating the normal faults in northern Tibet. This would have also caused concomitant asthenospheric upwelling, which 
could account for not only the high-temperature features within the upper mantle but also melting of the remaining enriched lithospheric mantle to form the potassic volcanism (Turner et al., 1996). In southern Tibet, underthrusting of the Indian lithosphere may have had two major effects. First, it gradually shut off the heat from the asthenosphere and eventually terminated the lithospheric removal-induced magmatism at $\sim 13-10 \mathrm{Ma}$; thus, no igneous activity younger than this age occurs in the southern Tibetan plateau despite the existence of pervasive partial melts and/or hydrous fluids at mid-crustal levels (Nelson et al., 1996; Wei et al., 2001). Second, it offers a support that holds up the high and flat topography (Beghoul et al., 1993; Fielding, 1996; Owens and Zandt, 1997); thus, the elevation of this region has remained unchanged over the past $\sim 15 \mathrm{Ma}$ (Spicer et al., 2003).

\section{Summary and further implications}

Post-collisional magmatism on Tibet shows systematic spatial and temporal variations, which we believe can provide the most straightforward constraints on the geodynamic processes that evolved at depth to form the immense plateau. This observation leads us to propose a revised tectonomagmatic evolution model for Tibet, involving slab rollback and subsequent breakup, back-arc extension and basin formation, convective removal of thickened lithospheric lid, and consequently northward underthrusting of the Indian mantle lithosphere. Our model suggests that the Tibetan plateau evolved and rose diachronously from south to north. Starting with a narrow mountain range along the Gangdese magmatic arc since Cretaceous time, it is argued that southern Tibet underwent two main stages of uplift at $\sim 45$ and $\sim 26 \mathrm{Ma}$, in response to the breakoff of the Neo-Tethyan slab and the loss of gigantic Lhasa lithospheric root, respectively. The slab breakoff did not cause magma generation but led to the initiation of "hard collision" between India and Asia, which greatly thickened the lower part of the Lhasa lithosphere. This model explains the general lack of upper crustal contraction and shortening in the early stage of the Tibetan tectonic evolution. It is emphasized that the Indian cratonic mantle lithosphere could have begun moving northward only after the greatly thickened Lhasa lithospheric keel was removed, a turning point from which the southern part of the Tibetan plateau was created and major tectonomagmatism in the Himalayas started. Since then, the Tibetan evolution has been controlled by the northward advancing Indian mantle lithosphere. Therefore, the northern plateau may have attained its presentday elevation not earlier than $\sim 13 \mathrm{Ma}$, when continued northward squeezing of the underthrust Indian lithosphere eventually made the lower part of thickened lithospheres beneath the western Qiangtang and Songpan-Ganze terranes unstable that it began to founder. We address that our model differs fundamentally from the Indian crustal underthrusting model proposed recently by DeCelles et al. (2002) for the Himalayan-Tibetan orogenesis that predicts a northward migrating topographic front due solely to the insertion of Greater Indian lower crust, assuming that the Asian lithospheric keel beneath Tibet has been already evacuated before the initial impingement of Greater India.

Our model is compatible with the requirement of producing a flat plateau (Fielding et al., 1994), which, marked by low slopes especially on northern Tibet, implies that there has been little contraction and shortening in the upper crust since the latest Tertiary (Fielding et al., 1994; Fielding, 1996; Liu and Wang, 2001). To maintain the topography of the plateau, we follow but slightly modify the scenarios presented by Beghoul et al. (1993), who regarded the southern and the northern parts of the Tibetan plateau to have been supported by two different compensation mechanisms. These are, respectively, northward underthrusting of the Indian lithosphere in the south and upward replacement of the basal lithosphere by hotter and lighter asthenosphere in the north. The latter process, supported by magnetotelluric data (Wei et al., 2001), may be facilitated by eastward lower crustal flow that can work to level the elevation (cf. Bird, 1991). The prevailing melts in the Tibetan deep crust, if do exist, do not necessarily only reflect partial melting of the crust itself. In northern Tibet, where potassic volcanism is active, this may instead be interpreted as extensive underplating of magmas derived from the lithospheric mantle, which is capable of upward transport of the heat required to explain the extraordinarily high Poisson's ratios (Owens and Zandt, 1997) and con- 
ductivity (Wei et al., 2001). If mantle-derived magmas did intrude extensively into the lower crust, close to or above the Moho (Fig. 7e), they may have served as an efficient process producing not only crustal growth and thickening but also significant melting of the overlying crust. This may have triggered lower crustal flow, which, however, is more likely to be a geologically young feature that would have happened after the high topography of the northern Tibetan plateau had been achieved (Beghoul et al., 1993). Thus, in the Paleogene, the Qiangtang terrane under which potassic magmatism could have also caused substantial magmatic underplating in the lower crust (Fig. 7b) had an elevation too low to flow.

The geochemical argument for generating adakitic magmas during $\sim 26$ and $10 \mathrm{Ma}$ from an eclogitized mafic lower crust beneath southern Tibet seems at odds with geophysical data which suggest the existence of pervasive partial melts and/or fluids presently in the mid-crust of the Lhasa terrane. The latter has led some workers (e.g., Searle, 1999) to propose a genetic correlation to the Miocene Himalayan leucogranites and thus developed a fascinating idea of southward extrusion of the middle crust from southern Tibet via a low-viscosity channel (e.g., Beaumont et al., 2001; Hodges, 2000). We remark that the adakites are geochemically distinct from the coeval leucogranites presumably resulting from Greater Himalayan crustal anatexis. This distinction does not back up the notion that the leucogranites are the extruded equivalent of crustal partial melts underneath southern Tibet. The melting phenomenon, if it does exist so extensively in the mid-crust levels of the Lhasa terrane (Nelson et al., 1996), needs to be reconciled with the scarcity of such melts at the surface along the widespread and still active north-south-striking normal fault systems in southern Tibet, where no igneous activity has been identified since $\sim 10 \mathrm{Ma}$. Therefore, there is no basis for Yin (2000) to affiliate modern east-west extension in the region with a mantle-derived "synrifting magmatism", which does not exist presently, not to mention that the epicenters of the "mantle earthquakes", which form the basis of Yin (2000)'s model, have been relocated to shallower depths above the Moho (Jackson, 2002). Based on the observation of several temporal-spatial "mis- matches" between the normal faulting and the ultrapotassic magmatism in southern Tibet, Lee et al. (2003a) questioned the commonly suggested direct link between these two events and argued that the former represents crustal features whose development manifests a combined effect of oblique convergence of India with Asia and northward underthrusting of the Indian lithosphere.

The $\sim 5-\mathrm{km}$-high, uniform Tibetan plateau is considered unlikely to be just a coincidence of the temporally and spatially heterogeneous geodynamic processes that have been operating in the Tibetan tectonomagmatic evolution. Instead, the height and flatness are more likely to reflect the maximum sustainable potential-energy level of this immense region, and after this level is achieved, further uplift may be dissipated by various processes such as gravitational collapse and lithospheric thinning (Houseman et al., 1981; Molnar et al., 1993; England and Molnar, 1997), eastward lower crustal flow (Bird, 1991; Beghoul et al., 1993; Royden et al., 1997; Clark and Royden, 2000), eastward block extrusion of northern Tibet along the major trans-lithospheric strike-slip faults (Tapponnier et al., 1982, 2001) followed by a clockwise rotation around the eastern Hiamalayan Syntaxis (Wang et al., 2001b; Lee et al., 2003a), and southward extrusion of the middle crust from southern Tibet (Searle, 1999; Beaumont et al., 2001; Hodges et al., 2001). These potential-energy dissipation processes may have been associated with, and therefore balanced by, the support from the underthrusting Indian mantle lithosphere. Consequently, a semi-equilibrium or "quasi-steady" state (Hodges, 2000) of the Tibetan tectonic evolution has been reached and maintained since at least midMiocene time. Under such circumstances, any existing models which address only a particular geodynamic process through time for the entire plateau have the problem of oversimplification and need to be taken for granted with great caution.

\section{Acknowledgements}

We thank J.-Q. Ji for help with arranging field trips to southern Tibet, Cin-Ty Lee, J.-P. Burg, J.A. Pearce, and $\mathrm{H}$. Williams for comments and/or suggestions on the early versions of the manuscript, and P.T. 
Robinson and A.D. Smith for journal reviews. This study benefited from financial supports by the National Science Council, Taiwan.

\section{References}

Aitchison, J.C., Abrajevitvh, A., Ali, J.R., Badengzhu, J.R., Davis, A.M., Luo, H., Liu, J.-B., McDermid, I.R.C., Ziabrev, S., 2003. New insights into the evolution of the Yarlung Tsangpo suture zone, Xizang (Tibet), China. Episodes 25, 90-94.

Aitchison, J.C., Davis, A.M., Badengzhu, Luo, H., 2003. The Gangdese thrust: a phantom structure that did not raise Tibet. Terra Nova 15, 155-162 (doi: 10.1046/j.1365-3121).

Allegrè, C.J., et al., 1984. Structure and evolution of the HimalayaTibet orogenic belt. Nature 307, 17-22.

Allmendinger, R.W., Jordan, T.E., Kay, S.M., Isacks, B.L., 1997. The evolution of the Altiplano-Puna plateau of the central Andes. Annu. Rev. Earth Planet. Sci. 25, 139-174.

Armijo, R., Tapponnier, P., Mercier, J.L., Han, T.-L., 1986. Quaternary extension in southern Tibet: field observations and tectonic implications. J. Geophys. Res. 91, 13803-13872.

Arnaud, N.O., Vidal, Ph., Tapponnier, P., Matte, Ph., Deng, W.-M., 1992. The high $\mathrm{K}_{2} \mathrm{O}$ volcanism of northwestern Tibet: geochemistry and tectonic implications. Earth Planet. Sci. Lett. 111, $355-367$.

Barragan, R., Geist, D., Hall, M., Larson, P., Kurz, M., 1998. Subduction controls on the compositions of lavas from the Ecuadorian Andes. Earth Planet. Sci. Lett. 154, 153-166.

Beaumont, C., Jamieson, R.A., Nguyen, M.N., Lee, B., 2001. Himalayan tectonics explained by extrusion of a low-viscosity crustal channel coupled to focused surface denudation. Nature 414, 738-742.

Beghoul, N., Barazangi, M., Isacks, B.L., 1993. Lithospheric structure of Tibet and western North America: mechanisms of uplift and a comparative study. J. Geophys. Res. 98, 1997-2016.

Bertrand, G., Rangin, C., Maluski, H., Bellon, H., 2001. Diachronous cooling along the Mogok metamorphic belt (Shan scarp, Myanmar): the trace of the northward migration of the Indian syntaxis. J. Asian Earth Sci. 19, 649-659.

Bird, P., 1991. Lateral extrusion of lower crust from under high topography, in the isostatic limit. J. Geophys. Res. 96, 10275-10286.

Blisniuk, P.M., Hacker, B.R., Glodny, J., Ratschbacher, L., Bi, S., Wu, Z., McWilliams, M.O., Calvert, A., 2001. Normal faulting in central Tibet since at least 13.5 Myr ago. Nature 412, $628-632$.

Burchfiel, B.C., Molnar, P., Zhao, Z., Liang, K., Wang, S., Huang, M., Sutter, J., 1989. Geology of the Ulugh Muztagh area, northern Tibet. Earth Planet. Sci. Lett. 94, 57-70.

Burchfiel, B.C., Chen, Z., Hodges, K.V., Liu, Y., Royden, L.H., 1992. The south Tibetan detachment system, Himalayan Orogen: extension contemporaneous with and parallel to shortening in a continental mountain belt. Spec. Pap. - Geol. Soc. Am. 269, $1-41$.

Chalot-Prat, F., Girbacea, R., 2000. Partial delamination of conti- nental mantle lithosphere, uplift-related crust-mantle decoupling, volcanism and basin formation: a new model for the Pliocene-Quaternary evolution of the southern east-Carpathians, Romania. Tectonophysics 327, 83-107.

Chemenda, A.I., Burg, J.-P., Mattauer, M., 2000. Evolutionary model of the Himalaya-Tibet system: geopoem based on new modeling, geological and geophysical data. Earth Planet. Sci. Lett. 174, 397-409.

Chu, M.-F., Chung, S.-L., Xie, Y.-W., Zhang, Y.-Q., 2004. Late Paleogene potassic magmatism in eastern Tibet: major and trace element and $\mathrm{Sr}-\mathrm{Nd}$ isotope constraints for the petrogenesis and mantle source characteristics. (To be submitted).

Chung, S.-L., Lee, T.-Y., Lo, C.-H., Wang, P.-L., Chen, C.-Y., Nguyen, T.Y., Tran, T.H., Wu, G., 1997. Intraplate extension prior to continental extrusion along the Ailao Shan-Red River shear zone. Geology 25, 311-314.

Chung, S.-L., Lo, C.-H., Lee, T.-Y., Zhang, Y.-Q., Xie, Y.-W., Li, X.-H., Wang, K.-L., Wang, P.-L., 1998. Diachronous uplift of the Tibetan plateau starting $40 \mathrm{Myr}$ ago. Nature 394, $769-773$.

Chung, S.-L., Liu, D.-Y., Ji, J.-Q., Chu, M.-F., Lee, H.-Y., Wen, D.-J., Lo, C.-H., Lee, T.-Y., Qian, Q., Zhang, Q., 2003. Adakites from continental collision zones: melting of thickened lower crust beneath southern Tibet. Geology 31, 1021-1024.

Clark, M.K., Royden, L.H., 2000. Topographic ooze: building the eastern margin of Tibet by lower crustal flow. Geology 28 , $703-706$.

Coleman, M.E., Hodges, K.V., 1995. Evidence for Tibetan plateau uplift before $14 \mathrm{Myr}$ ago from a new minimum estimate for east-west extension. Nature 374, 49-52.

Copeland, P., Harrison, T.M., Pan, Y., Kidd, W.S.F., Roden, M., Zhang, Y.-Q., 1995. Thermal evolution of the Gangdese batholith, southern Tibet: a history of episodic unroofing. Tectonics 14, 223-236.

Copper, K.M., Reid, M.R., Dunbar, N.W., McIntosh, W.C., 2002. Origin of mafic magmas beneath northwestern Tibet: constraints from ${ }^{230} \mathrm{Th}-{ }^{238} \mathrm{U}$ disequilibria. Geochem. Geophys. Geosyst. 3 (11), 1065 (doi: 10.1029/2002GC000332).

Coulon, C., Maluski, H., Bollinger, C., Wang, S., 1986. Mesocoic and Cenozoic volcanic rocks from central and southern Tibet: ${ }^{39} \mathrm{Ar} /{ }^{40} \mathrm{Ar}$ dating, petrological characteristics and geodynamical significance. Earth Planet. Sci. Lett. 79, 281-302.

Debon, F., Le Fort, P., Sheppard, S.M.F., Sonet, J., 1986. The four plutonic belts of the trans-Himalaya-Himalaya: a chemical, mineralogical, isotopic and chronological synthesis along a Tibet-Nepal section. J. Petrol. 27, 219-250.

DeCelles, P.G., Robinson, D.M., Zandt, G., 2002. Implications of shortening in the Himalayan fold-thrust belt for uplift of the Tibetan plateau. Tectonics 21 (6), 1062 (doi: 10.1029/ 2001TC001322).

Defant, M.J., Drummond, M.S., 1990. Derivation of some modern arc magmas by melting of young subducted lithosphere. Nature 347, $662-665$.

Deng, W.-M., 1998. Cenozoic Intraplate Volcanic Rocks in the Northern Qinghai-Xizang Plateau Geol. Publ. House, Beijing. $180 \mathrm{pp}$.

Deng, W.-M., Sun, H., Zhang, Y.-Q., 2001. Petrogenesis of Ceno- 
zoic potassic volcanic rocks in Nangqian basin. Chin. J. Geol. 36, 304-318.

Ding, L., Zhang, J.-J., Zhou, Y., Deng, W.-M., Xu, R.-H., Zhong, D.-L., 1999. Tectonic implication on the lithospheric evolution of the Tibetan plateau: petrology and geochemistry of sodic and ultrapotassic volcanism in northern Tibet. Acta Pet. Sin. 15, $408-423$.

Ding, L., Kapp, P., Yin, A., Deng, W.-M., Zhong, D.-L., 2003. Early Tertiary volcanism in the Qiangtang terrane of central Tibet: evidence for a transition from oceanic to continental subduction. J. Petrol. 44, 1833-1865.

England, P., Houseman, G., 1986. Finite strain calculations of continental deformation: 2. Comparison with the India-Asia collision zone. J. Geophys. Res. 91, 3664-3676.

England, P., Molnar, P., 1997. Active deformation of Asia: from kinematics to dynamics. Science 278, 647-650.

England, P., Searle, M., 1986. The Cretaceous-Tertiary deformation of the Lhasa block and its implications for crustal thickening in Tibet. Tectonics 5, 1-14.

Fielding, E.J., 1996. Tibet uplift and erosion. Tectonophysics 260, $55-84$.

Fielding, E.J., Isacks, B.L., Barazangi, M., Duncan, C.C., 1994. How flat is Tibet? Geology 22, 163-167.

Galvé, A., Hirn, A., Jiang, M., Gallart, J., de Voogd, B., Lépine, J.-C., Diaz, J., Wang, Y., Qian, H., 2002. Modes of raising northeastern Tibet probed by explosion seismology. Earth Planet. Sci. Lett. 203, 35-43.

Guillot, S., Allemand, P., 2002. Two-dimensional thermal modeling of the early tectonometamorphic evolution in central Himalaya. J. Geodyn. 34, 77-98.

Hacker, B.R., Gnos, E., Ratschbacher, L., Grove, M., McWilliams, M., Sobolev, S.V., Jiang, W., Wu, Z., 2000. Hot and dry deep crustal xenoliths from Tibet. Science 287, 2463-2466.

Haines, S.S., Klemperer, S.L., Brown, L., Guo, J., Mechie, J., Meissner, R., Ross, A., Zhao, W., 2003. INDEPTH III seismic data: from surface observations to deep crustal processes in Tibet. Tectonics 22 (1), 1001 (doi: 10.1029/2001TC001305).

Harris, N.B.W., Xu, R.-H., Lewis, C.L., Jin, C.-W., 1988a. Plutonic rocks of the 1985 Tibet Geotraverse: Lhasa to Golmud. Philos. Trans. R. Soc. Lond. A327, 145-168.

Harris, N.B.W., Xu, R.-H., Lewis, C.L., Hawkesworth, C.J., Zhang, Y.-Q., 1988b. Isotope geochemistry of the 1985 Tibet Geotraverse: Lhasa to Golmud. Philos. Trans. R. Soc. Lond. A327, $263-285$.

Harrison, T.M., Copeland, P., Kidd, W.S.F., Yin, A., 1992. Raising Tibet. Science 255, 1663-1670.

Harrison, T.M., Lovera, O.M., Grove, M., 1997. New insights into the origin of two contrasting Himalayan granite belts. Geology 25, 899-902.

Harrison, T.M., Yin, A., Grove, M., Lovera, O.M., 2000. The Zedong window: a record of superposed Tertiary convergence in southeastern Tibet. J. Geophys. Res. 105, 19211-19230.

Hodges, K.V., 2000. Tectonics of the Himalaya and southern Tibet from two perspectives. Geol. Soc. Amer. Bull. 112, 324-350.

Hodges, K.V., Parrish, R., Housh, T., Lux, D., Burchfiel, B.C., Royden, L., Chen, Z., 1992. Simultaneous Miocene extension and shortening in the Himalayan orogen. Science 258, 1466-1470.
Hodges, K.V., Hurtado, J.M., Whipple, K.X., 2001. Southward extrusion of Tibetan crust and its effect on Himalayan tectonics. Tectonics 20, 799-809.

Holt, W.E., 2000. Correlated crust and mantle strain fields in Tibet. Geology 28, 67-70.

Horton, B.K., Yin, A., Spurlin, M.S., Zhou, J., Wang, J.-H., 2002. Paleocene-Eocene syncontractional sedimentation in narrow, lacustrine-dominated basins of east-central Tibet. Geol. Soc. Amer. Bull. 114, 771-786.

Houseman, G.A., McKenzie, D.P., Molnar, P., 1981. Convective instability of a thickened boundary layer and its relevance for the thermal evolution of continental convergent belts. J. Geophys. Res. 86, 6115-6132.

Huang, W.-C., Ni, J.F., Tilmann, F., Nelson, D., Guo, J., Zhao, W., Mechie, J., Kind, R., Saul, J., Rapine, R., Hearn, T.M., 2000. Seismic polarization anisotropy beneath the central Tibetan plateau. J. Geophys. Res. 105, 27979-27989.

Jackson, J., 2002. Strength of the continental lithosphere: time to abandon the jelly sandwich? GSA Today, 4-10 (Sept.).

Jiang, W., Mo, X.-X., Zhao, C., Guo, T., Zhang, S., 1999. Geochemistry of granitoids and mafic microgranular enclaves in the Gangdese belt. Acta Pet. Sin. 15, 89-97.

Kapp, P., Yin, A., Manning, C., Murphy, M.A., Harrison, T.M., Spurlin, M., Ding, L., Deng, X.-G., Wu, C.-M., 2000. Blueschist-bearing metamorphic core complexes in the Qiangtang block reveal deep crustal structure of northern Tibet. Geology $28,19-22$.

Kay, R.W., Kay, S.M., 2002. Andean adakites: three ways to make them. Acta Pet. Sin. 18, 303-311.

Kay, S.M., Coira, B., Viramonte, J., 1994. Young mafic back arc volcanic rocks as indicators of continental lithospheric delamination beneath the Argentine Puna plateau, central Andes. J. Geophys. Res. 99, 24323-24339.

Kind, R., Yuan, X., Saul, J., Nelson, D., Sobolev, S.V., Mechie, J., Zhao, W., Kosarev, G., Ni, J., Achauer, U., Jiang, M., 2002. Seismic images of crust and upper mantle beneath Tibet: evidence for Eurasian plate subduction. Science 298, 1219-1221.

Klootwijk, C.T., Conaghan, P.J., Powell, C. McA., 1985. The Himalayan Arc: large-scale continental subduction, oroclinal bending and back-arc spreading. Earth Planet. Sci. Lett. 75, 167-183.

Kohn, M.J., Parkinson, C.D., 2002. Petrologic case for Eocene slab breakoff during the Indo-Asian collision. Geology 30, 591-594.

Kosarev, G., Kind, R., Sobolev, S.V., Yuan, X., Hanka, W., Oreshin, S., 1999. Seismic evidence for a detached Indian lithospheric mantle beneath Tibet. Science 283, 1306-1309.

Lee, T.-Y., Lawver, L.A., 1995. Cenozoic plate reconstruction of Southeast Asia. Tectonophysics 251, 85-138.

Lee, H.-Y., Chung, S.-L., Wen, D.-J., Zhang, Y.-Q., Xie, Y.-W., Wang, J.-R., Yang, T.F., Lo, C.-H., Lee, T.-Y., Li, H.-M., 2001. New geochronological data from the eastern Gangdese batholith with implications for the dextral movement of the Jiali fault, SE Tibet. J. Conf. Abstr. 6, 331.

Lee, H.-Y., Chung, S.-L., Wang, J.-R., Wen, D.-J., Lo, C.-H., Yang T.F., Zhang, Y.-Q., Xie, Y.-W., Lee, T.-Y., Wu, G.-Y., Ji, J.-Q., 2003a. Miocene Jiali faulting and its implications for Tibetan tectonic evolution. Earth Planet. Sci. Lett. 205, 185-194. 
Lee, H.-Y., Chung, S.-L., Wen, D.-J., Ji, J.-Q., Qian, Q., Lo, C.-H., Lee, T.-Y., 2003b. Age and geochemical constraints on the genesis of the Paleogene Linzizong volcanic successions in southern Tibet. Abstr. EGS-AGU-EUG Joint Meeting, p. 487.

Le Fort, P., Cuney, M., Deniel, C., France-Lanord, C., Sheppard, S.M.F., Upreti, B.N., Vidal, P., 1987. Crustal generation of Himalayan leucogranites. Tectonophysics 134, 39-57.

Le Maitre, R.W. (Ed.), 2002. Igneous Rocks: A Classification and Glossary of Terms, 2nd ed. Cambridge Univ. Press, Cambridge, UK, $236 \mathrm{pp}$.

Li, X.-H., Zhou, H.-W., Chung, S.-L., Lo, C.-H., Wei, G.-J., Liu, Y., Lee, C.Y., 2002. Geochemical and $\mathrm{Sr}-\mathrm{Nd}$ isotopic characteristics of late Paleogene ultrapotassic magmatism in SE Tibet. Int. Geol. Rev. 44, 559-574.

Liu, Z.-F., Wang, C.-S., 2001. Facies analysis and depositional systems of Cenozoic sediments in the Hoh Xil basin, northern Tibet. Sediment. Geol. 140, 251-270.

Liu, Z.-F., Wang, C.-S., Yi, H.-S., 2000. Mass accumulation in the Cenozoic Hoh Xil basin, northern Tibet. Earth Sci. Front. 7, 161162 (15th Himalaya-Karakoram-Tibet Workshop Abstr.).

Mahéo, G., Guillot, S., Blichert-Toft, J., Rolland, Y., Pecher, A., 2002. A slab breakoff model for the Neogene thermal evolution of South karakorum and South Tibet. Earth Planet. Sci. Lett. $195,45-58$.

Maluski, H., Proust, F., Xiao, X.-C., 1982. ${ }^{39} \mathrm{Ar} /{ }^{40} \mathrm{Ar}$ dating of the trans-Himalayan calc-alkaline magmatism of southern Tibet. Nature 298, 152-154.

Martin, H., 1998. Adakitic magmas: modern analogues of Archaean granitoids. Lithos 46, 411-429.

McKenna, L.W., Walker, J.D., 1990. Geochemistry of crustally derived leucocratic igneous rocks from the Ulugh Muztagh area, northern Tibet and their implications for the formation of the Tibetan plateau. J. Geophys. Res. 95, 21483-21502.

McNamara, D.E., Owens, T.J., Walter, W.R., 1995. Observations of regional phase propagation across the Tibetan plateau. J. Geophys. Res. 100, 22215-22229.

Menzies, M.A. (Ed.), 1990. Continental Mantle. Clarendon Press, Oxford. $184 \mathrm{pp}$.

Miller, C., Schuster, R., Klötzli, U., Frank, W., Purtscheller, F., 1999. Post-collisional potassic and ultrapotassic magmatism in $\mathrm{SW}$ Tibet: geochemical and $\mathrm{Sr}-\mathrm{Nd}-\mathrm{Pb}-\mathrm{O}$ isotopic constraints for mantle source characteristics and petrogenesis. J. Petrol. 40, $1399-1424$.

Molnar, P., England, P., Martinod, J., 1993. Mantle dynamics, the uplift of the Tibetan plateau, and the Indian monsoon. Rev. Geophys. 31, 357-396.

Morley, C.K., 2001. Combined escape tectonics and subduction rollback-back arc extension: a model for the evolution of Tertiary rift basins in Thailand, Malaysia and Laos. J. Geol. Soc. (Lond.) 158, 461-474.

Murphy, M.A., Yin, A., Harrison, T.M., Dürr, S.B., Chen, Z., Ryerson, F.J., Kidd, W.S.F., Wang, X., Zhou, X., 1997. Did the IndoAsian collision along create the Tibetan plateau? Geology 25, 719-722.

Nelson, D.R., 1992. Isotopic characteristics of potassic rocks: evidence for the involvement of subducted sediments in magma genesis. Lithos 28, 403-420.
Nelson, K.D., et al., 1996. An INDEPTH view of the structure of the lithosphere beneath Tibet. Science 274, 1684-1688.

Owens, T.J., Zandt, G., 1997. Implications of crustal property variations for models of Tibetan plateau evolution. Nature 387 , $37-43$.

Paul, P., et al., 2001. The motion and active deformation of India. Geophys. Res. Lett. 28, 647-650.

Pearce, J.A., Mei, H., 1988. Volcanic rocks of the 1985 Tibet Geotraverse: Lhasa to Golmud. Philos. Trans. R. Soc. Lond. A327, $169-201$.

Peccerillo, A., Taylor, D.R., 1976. Geochemistry of Eocene calcalkaline volcanic rocks from the Kastamonu area, northern Turkey. Contrib. Mineral. Petrol. 58, 63-91.

Platt, J.P., England, P., 1994. Convective removal of lithosphere beneath mountain belts: thermal and mechanical consequences. Am. J. Sci. 294, 307-336.

Powell, C. McA., 1986. Continental underplating model for the rise of the Tibetan Plateau. Earth Planet. Sci. Lett. 81, 79-94.

Qu, X.-M., Hou, Z.-Q., Huang, W., 2001. The Gangdese porphyry copper belt: a second Yulong copper belt from southern Tibet? Miner. Depos. 20, 355-366.

Roger, F., Tapponnier, P., Arnaud, N., Schärer, U., Brunel, M., Xu, Z., Yang, J., 2000. An Eocene magmatic belt across central Tibet: mantle subduction triggered by the Indian collision? Terra Nova $12,102-108$.

Rogers, R.D., Karason, H., van der Hilst, R.D., 2002. Epeirogenic uplift above a detached slab in northern central America. Geology $30,1031-1034$.

Rowley, D.B., 1998. Minimum age of initiation of collision between India and Asia north of Everest based on the subsidence history of the Zhepure mountain section. J. Geol. 106, $229-235$.

Royden, L.H., Burchfiel, B.C., King, R.W., Wang, E., Chen, Z., Shen, F., Liu, Y., 1997. Surface deformation and lower crustal flow in eastern Tibet. Science 276, 788-790.

Rudnick, R.L., 1995. Making continental crust. Nature 378, 571-578.

Schaefer, B.F., Turner, S.P., Rogers, N.W., Hawkesworth, C.J., Williams, H.M., Pearson, D.G., Nowell, G.M., 2000. Re-Os isotope characteristics of postorogenic lavas: implications for the nature of young lithospheric mantle and its contribution to basaltic magmas. Geology 28, 563-566.

Schärer, U., Allègre, C.J., 1984. U-Pb geochronology of the Gangdese (trans-Himalaya) plutonism in the Lhasa-Xigaze region, Tibet. Earth Planet. Sci. Lett. 69, 311-320.

Searle, M.P., 1999. Extensional and compressional faults in the Everest-Lhotse massif, Khumbu Himalaya, Nepal. J. Geol. Soc. (Lond.) 156, 227-240.

Sobel, E.R., Arnaud, N., 2000. Cretaceous-Paleogene basaltic rocks of the Tuyon basin, NW China and the Kyrgyz Tian Shan: the trace of a small plume. Lithos 50, 191-215.

Spicer, R.A., Harris, N.B.W., Widdowson, M., Herman, A.B., Guo, S., Valdes, P.J., Wolfe, J.A., Kelley, S., 2003. Constant elevation of southern Tibet over the past 15 million years. Nature 421 , $622-624$.

Sun, S.-S., McDonough, W.L., 1989. Chemical and isotopic systematics of oceanic basalts: implications for mantle composition 
and processes. In: Saunders, A.D., Norry, M.J. (Eds.), Magmatism in the Ocean Basins. Spec. Publ. - Geol. Soc. Lond., vol. 42, pp. 313-345.

Tapponnier, P., Peltzer, G., Armijo, R., Le Dain, A., Cobbold, P., 1982. Propagating extrusion tectonics in Asia: new insights from simple experiments with plasticine. Geology 10, 611-616.

Tapponnier, P., Xu, Z., Roger, F., Meyer, B., Arnaud, N., Wittlinger, G., Yang, J., 2001. Oblique stepwise rise and growth of the Tibet plateau. Science 294, 1671-1677.

Tatsumi, Y., Eggins, S., 1995. Subduction Zone Magmatism Blackwell, Cambridge. $200 \mathrm{pp}$.

Thompson, A.B., Schulmann, K., Jezek, J., Tolar, V., 2001. Thermally softened continental extensional zones (arcs and rifts) as precursors to thickened orogenic belts. Tectonophysics 332, $115-141$.

Tilmann, F., Ni, J., INDEPTH III Seismic Team, 2003. Seismic imaging of the downwelling Indian lithosphere beneath central Tibet. Science 300, 1424-1427.

Tu, G.-Z., et al., 1982. Geochemistry of the Granitoids from Southern Tibet Sci. Press, Beijing. 190 pp.

Turner, S., Hawkesworth, C.J., Liu, J., Rogers, N., Kelley, S., van Calsteren, P., 1993. Timing of Tibetan uplift constrained by analysis of volcanic rocks. Nature $364,50-54$.

Turner, S., Arnaud, N., Liu, J., Rogers, N., Hawkesworth, C., Harris, N., Kelley, S., van Calsteren, P., Deng, W.-M., 1996. Postcollisional, shoshonitic volcanism on the Tibetan plateau: implications for convective thinning of the lithosphere and the source of ocean island basalts. J. Petrol. 37, 45-71.

Van der Voo, R., Spakman, W., Bijwaard, H., 1999. Tethyan subducted slabs under India. Earth Planet. Sci. Lett. 171, 7-20.

Wang, J.-H., Yin, A., Harrison, T.M., Grove, M., Zhang, Y.-Q., Xie, G.-H., 2001a. A tectonic model for igneous activities in the eastern Indo-Asian collision zone. Earth Planet. Sci. Lett. 188, $123-133$.

Wang, Q., et al., 2001b. Present-day crustal deformation in China constrained by global positioning system measurements. Science 294, 574-577.

Wei, W., et al., 2001. Detection of widespread fluids in the Tibetan crust by magnetotelluric studies. Science 292, 716-718.

Wen, D.-J., Chung, S.-L., Liu, D.-Y., Ji, J.-Q., Chu, M.-F., Song, B., Lo, C.-H., Lee, T.-Y., 2003. New SHRIMP U-Pb zircon ages from the Gangdese batholith and implications for the trans-Himalayan magmatic evolution. Abst. EGS-AGU-EUG Joint Meeting, p. 494.

Willett, S.D., Beaumont, C., 1994. Subduction of Asian lithospheric mantle beneath Tibet inferred from models of continental collision. Nature 369, 642-645.
Williams, H., Turner, S., Kelley, S., Harris, N., 2001. Age of composition of dikes in southern Tibet: new constraints on the timing of east-west extension and its relationship to postcollisional magmatism. Geology 29, 339-342.

Wortel, M.J.R., Spakman, W., 2000. Subduction and slab detachment in the Mediterranean-Carpathian region. Science 290, 1910-1917.

Xu, R.-H., Schärer, U., Allègre, C.-J., 1985. Magmatism and metamorphism in the Lhasa block (Tibet): a geochronological study. J. Geol. 93, 41-57.

Xu, Y.-G., Menzies, M.A., Thirlwall, M.F., Xie, G.-H., 2001. Exotic lithosphere mantle beneath the western Yangtze craton: petrogenetic links to Tibet using highly magnesian ultrapotassic rocks. Geology 29, 863-866.

Yin, A., 2000. Mode of Cenozoic east-west extension in Tibet suggesting a common origin of rifts in Asia during the IndoAsian collision. J. Geophys. Res. 105, 21745-21759.

Yin, A., Harrison, T.M., 2000. Geologic evolution of the Himalayan-Tibetan orogen. Annu. Rev. Earth Planet. Sci. 28, 211-280.

Yuan, X., Ni, J., Kind, R., Mechie, J., Sandvol, E., 1997. Lithospheric and upper mantle structure of southern Tibet from a seismological passive source experiment. J. Geophys. Res. 102, 27491-27500.

Zeitler, P.K., Meltzer, A.S., Koons, P.O., Craw, D., Hallet, B., Chamberlain, C.P., Kidd, W.S.F., Park, S.K., Seeber, L., Bishop, M., Shroder, J., 2001. Erosion, Himalayan geodynamics, and the geomorphology of metamorphism. GSA Today, 4-9 (Jan.).

Zhang, S., Karato, S., 1995. Lattice preferred orientation of olivine aggregates deformed in simple shear. Nature 375, 774-777.

Zhang, Y.-Q., Xie, Y.-W., Tu, G.-Z., 1987. Preliminary study of the alkali-rich intrusive rocks in the Ailaoshan-Jinshajiang belt and their bearing on rifting tectonics. Acta Pet. Sin. 3, 17-26.

Zhang, P., Molnar, P., Downs, W.R., 2001. Increased sedimentation rates and grain sizes 2-4 Myr ago due to the influence of climate change on erosion rates. Nature 410, 891-987.

Zhao, W.-L., Morgan, W.J., 1985. Uplift of Tibetan plateau. Tectonics 4, 359-369.

Zhao, W., et al., 2001a. Crustal structure of central Tibet as derived from project INDEPTH wide-angle seismic data. Geophys. J. Int. 145, 486-498.

Zhao, Z.-D., Mo, X.-X., Zhang, S., Guo, T., Zhou, S., Dong, G., Wang, Y., 2001b. Post-collisional magmatism in the Wuyu basin, southern Tibet. Sci. China, Ser. D: Earth Sci. 31, 20-26.

Zhu, L., Helmberger, D.V., 1998. Moho offset across the northern margin of the Tibetan plateau. Science 281, 1170-1172. 